Modern Human Origins and the Evolution of Behavior in the Later Pleistocene Record of South Asia ${ }^{1}$

\author{
by Hannah V. A. James and \\ Michael D. Petraglia
}

\begin{abstract}
The archaeological record of Later Pleistocene South Asia has a crucial role to play in our understanding of the evolution of modern human behavior and the dispersal of anatomically modern humans around the Old World. Later Pleistocene records of South Asia are here summarized and placed in the context of the modern-human-origins debate. Aspects of the South Asian record share familiar traits with other regions of the Old World, but South Asia also appears to have its own adaptive features and material culture developments. The fluctuating environment during the Later Pleistocene would have influenced the adaptations of anatomically modern and "archaic" humans, affecting population size, movement, and the usefulness of cultural innovations. On the basis of prevailing genetic, archaeological, and biogeographic information, it is hypothesized that Homo sapiens colonized South Asia as part of an early southern dispersal from Africa. The effect of demographic processes on the rate and direction of cultural change is proposed as an explanation for the lack of a "symbolic revolution" signaling the arrival of anatomically modern humans on the Indian subcontinent. Instead, the Late Paleolithic represents a diversification of adaptive behaviors that may be traced to the Middle Paleolithic.
\end{abstract}

HANNAH V. A. JAmes is a Ph.D. candidate in the Department of Biological Anthropology (University of Cambridge, Downing Street, Cambridge $\mathrm{CB}_{2}{ }_{3} \mathrm{DZ}$, England) and a member of the Leverhulme Centre for Human Evolutionary Studies. Born in I98I, she received a B.A. from the University of Oxford in 2002 and an M.Phil. from the University of Cambridge in 2003. Her thesis was entitled "Testing Theories of Modern Human Origins: The Middle Palaeolithic of South Asia."

I. Review of the South Asian evidence would not have been possible without the dedication of a large number of scholars working in the region. We thank our Indian colleagues, especially V. N. Misra, K. Paddayya, R. Korisettar, and S. Pappu, for their support and intellectual contributions to our research over the years. We appreciate the comments of C. Clarkson, P. Mellars, and P. Forster on an earlier draft of this article, as well as the comments of four anonymous reviewers. We alone are responsible for any errors and shortcomings in synthesizing and interpreting the South Asian record.
MICHAEL D. PETRAGLIA is Lecturer in Human Evolution, University of Cambridge, and a member of the Leverhulme Centre for Human Evolutionary Studies (m.petraglia@human-evol. cam.ac.uk). He was born in I960 and received his B.A. from New York University in 1982 and his Ph.D. from the University of New Mexico in I987. His publications include (with J. Schuldenrein and R. Korisettar), "Landscapes, Activity, and the Acheulean to Middle Paleolithic Transition in the Kaladgi Basin, India" (Eurasian Prehistory I[2]:3-24) (with P. LaPorta and K. Paddayya), "The First Acheulian Quarry in India: Stone Tool Manufacture, Biface Morphology, and Behaviors" (Journal of Anthropological Research 55:39-70), and (coedited with R. Korisettar) Early Human Behaviour in Global Context: The Rise and Diversity of the Lower Palaeolithic Record (London: Routledge Press, I998).

The present paper was submitted 27 VI 04 and accepted I 5 V 05.

The Later Pleistocene time frame (i.e., the period spanning ca. 250,000 to 10,000 years ago) has come under increasing scrutiny for identifying the origin and spread of modern humans. Genetic research on modern human populations (e.g., Cann 200I, Ingman et al. 2000), the analysis of ancient DNA (e.g., Carameli et al. 2003, Ovchinnikov et al. 200o), and fossil evidence (e.g., McDougall, Brown, and Fleagle 2005, Stringer 200I, White et al. 2003) indicate the origin of Homo sapiens in Africa by ca. I95,000-1 50,000 years ago. Archaeological evidence in Africa indicates that the first manifestation of modern human behavior occurs in the Later Pleistocene (e.g., McBrearty and Brooks 2000). However, debate continues concerning whether behavioral modernity slowly developed over a long period of time (e.g., Deacon and Wurz 2OOI) or appeared as a complete cultural package after 50,000 years ago (e.g., Klein 2000).

In recent years the actions that constitute "modern human behavior" and the extent to which they can be extrapolated from the archaeological record have come under discussion (e.g., Henshilwood and Marean 2003). Archaeologists have become increasingly interested not only in the origin of the modern behavioral package but also in the geographical variability in the sets of traits that are thought to define cultural modernity (e.g., d'Errico 2003, McBrearty and Brooks 2000). Such traits include specialized technology (e.g., blades, microliths, and the use of new materials such as bone), overtly symbolic behavior (e.g., art, artifact styles), chronological and geographical variability in artifact styles, artifact standardization, long-distance exchange networks, defined use of space within a settlement and landscape context, and ideas of group and self-identity. As a result of such research, the roots of at least some traits thought to be exclusively modern have been found to stretch back into the African Middle Pleistocene (McBrearty and Brooks 2000). In addition, accumulating evidence suggests that hominin species other than $H$. sapiens exhibited some of these behaviors (e.g., Bar-Yosef and Kuhn I999, $\mathrm{d}^{\prime}$ Errico 2003). The significance of such data to the modern-human-origins debate is dependent on the extent to which the populations that developed these traits contributed to the emergence of $H$. sapiens.

Research aimed at assessing the evolution of behavior remains concentrated on the contrasting records of Europe and Africa (e.g., Mellars 2002), the Near East being viewed 
as a transitional area occupied differentially by $H$. neanderthalensis and H. sapiens (e.g., Bar-Yosef I998a). The complexity of the Later Pleistocene records of these regions argues that the evolution of humans and their behavior cannot be understood without an awareness of the demographic and bio-cultural variability in all areas of the world. Yet, the gigantic landmasses of southern and eastern Asia play little or no role in modern debates about the evolution of behavior. With recent work in eastern Asia suggesting a very different pattern of behavioral development from that seen in Europe or Africa /Gao and Norton 2002), the question of how South Asia fits within the variability of behaviors associated with the last 250,000 years is increasingly important.

Situated geographically between the use of preparedcore technology in the West and its absence in the East, South Asia may represent the key to testing assumptions regarding environment, hominin species, demography, and resource intensification as explanations for differences in regional behaviors. While South Asia features heavily in models regarding the initial colonization of Australia (e.g., Lahr and Foley I994, I998; Stringer 2000), the archaeology of the Indian subcontinent has not been scrutinized from this perspective. This situation is rather absurd given that South Asia contains numerous identified archaeological sites and a sizable literature on hominin occupations (e.g., Kennedy 2000; Misra I989, 200I; Paddayya I984; Raju and Venkatasubbaiah 2002; Sankalia 1974). At present, the fossil, genetic, and archaeological evidence of South Asia has not been drawn together. This review attempts to place the material evidence of South Asia in the worldwide context of the human-origins debate, paying particular attention to the evolution of behavior and the dispersal of modern humans.

\section{Geography and Environments}

Represented by the modern nations of Bangladesh, India, Nepal, Pakistan, Sri Lanka, and the Maldives, South Asia is a region both characterized and constrained by major geographical features (Robinson I989). Bordered by the Himalayas to the north and the Arabian Sea and the Bay of Bengal to the west and east respectively, the Indian subcontinent is subdivided by numerous mountain ranges and plateaus, including the Western Ghats, the Eastern Ghats, and the Deccan Plateau. Numerous major river valleys, including the Indus, Narmada, Ganges, Godavari, and Krishna, cross the region. In the northwest, the Thar Desert (or Great Indian Desert) represents the easternmost extension of the midlatitude desert belts of Africa and Central Asia (Deotare et al. 2004). The major part of the Indian subcontinent has been a monsoonal environment since the Miocene, although fluctuations and shifts in its intensity, perhaps related to HimalayanTibetan uplifts, are registered through time (e.g., An et al. 200I, Retallack I995). Monsoonal shifts during the Pleistocene and marked seasonal changes in wet and dry periods are thought to have structured hominin settle- ment behaviors (Korisettar and Rajaguru I998, Korisettar and Ramesh 2002, Paddayya I982).

In the Later Pleistocene as today, South Asia's variable ecology and landscape provided a wide range of potential settings for hominin adaptations. Archaeological evidence clearly indicates Later Pleistocene occupation throughout the subcontinent (fig. I), including the settlement of both coastal and estuarine environments such as at the Ramayogi Agraharam locality (Rath, Thimma Reddy, and Vijaya Prakash I997) and in the Hiran Valley (Marathe I98I). Most sites have been identified in interior river valleys (Pappu and Deo I994, Raju I988), though this distribution may be partly a reflection of survey bias rather than a reliable record of hominin landscape use. The analysis of a number of ancient basins indicates that hominins sought areas where water (in the form of lakes, streams, and springs), lithic resources, and animal communities converged (Korisettar 2004). Archaeological sites are found in a range of topographic settings, including lowlands, uplands, and submountainous zones (Pappu I 995). Resource exploitation strategies involved both open-air contexts, such as Hokra and Gurha in the Thar Desert (Allchin, Goudie, and Hegde I978), and caves and rockshelters, such as Borra (Vijaya Prakash, Rath, and Krishna Rao I995) and Adamgarh (Joshi I978).

Terrestrial environments were subject to ecological changes as part of climatic oscillations throughout the Pleistocene. Paleoenvironmental data from both continental and oceanic records appear to indicate cycles of arid and humid conditions coupled with a trend toward increasing aridity as the Upper Pleistocene progressed. Increasingly open environments supplanted the mixed woodland and grassland ecosystems that characterized the Middle Pleistocene, with brackish swamps replacing plentiful freshwater sources (Misra 200I). With the exception of the ancient basins, most inland areas (including the Ganga Plain) were grasslands.

Within the Thar Desert, phases of aridity (and dune formation) are interspersed with periods of wetter, ameliorated climate (Andrews et al. I 998, Deotare et al. 2004, Kar et al. 200I). Such climatic and environmental fluctuations would have influenced the demographic profile of South Asia's ancient populations, as well as requiring cultural innovations. During periods of favorable climate (i.e., interglacial phases), increased resource availability would have enabled populations to expand. Unstable or less favorable conditions and their impact on the carrying capacity of the environment would have led to the reduction and fragmentation of populations. Various types of evidence support such patterns of demographic change. The ameliorated climate of oxygen isotope stage 3 coincides with wetter, more stable conditions in the Thar Desert (Andrews et al. I998, Deotare et al. 2004) and may correspond to a demographic expansion proposed on the basis of mitochondrial DNA analysis (Kivisild et al. I999a). Occupation in the Thar Desert becomes increasingly sparse and isolated after ca. 25,000 years ago, reflecting the heightened aridity and loss of available water sources (e.g., Deotare et al. 2004, Misra 


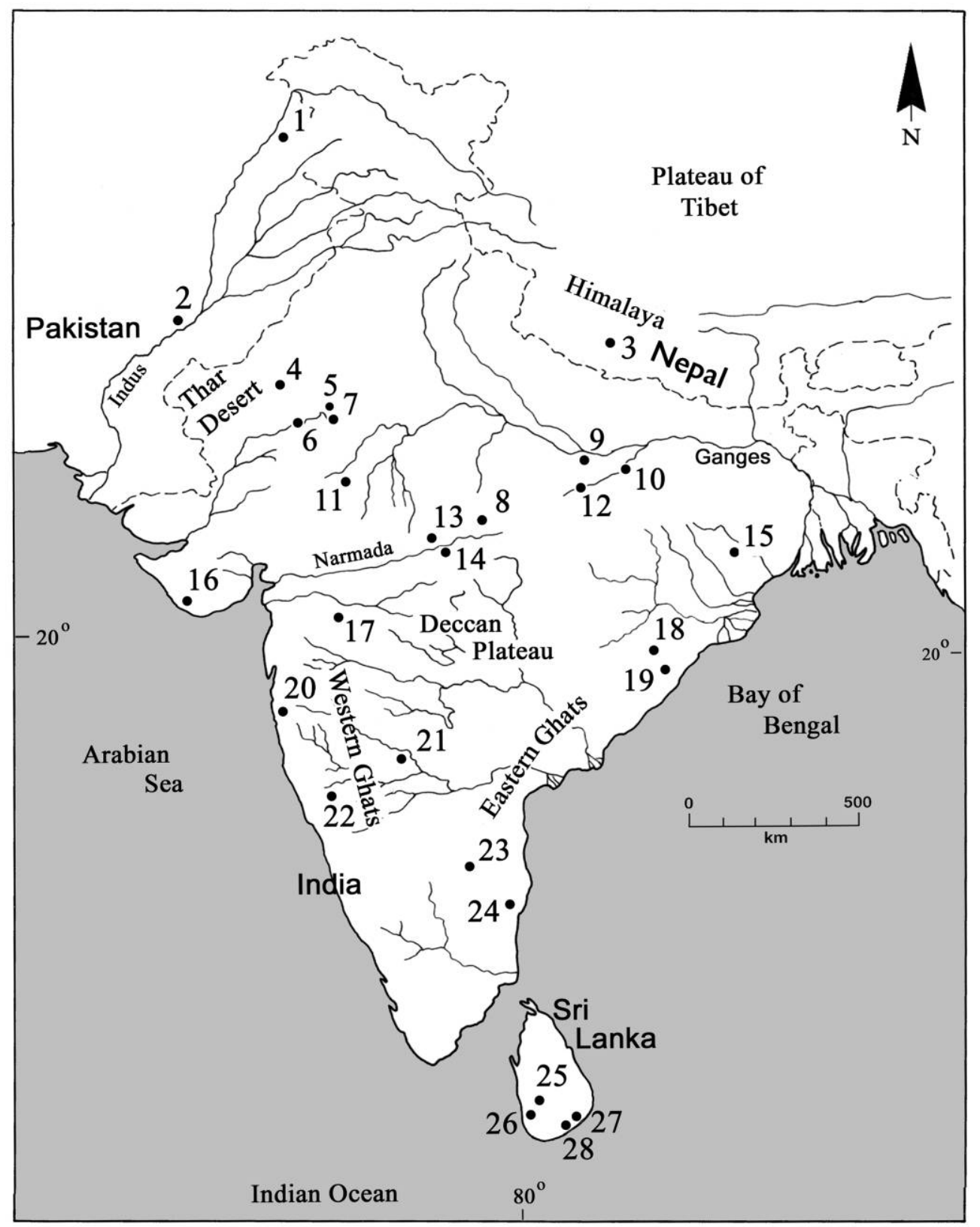

FIg. I. Principal Later Pleistocene localities in South Asia. Locations represent sites or site clusters. I, Site 55; 2, Chancha Baluch; 3, Dang-Deokhuri complex; 4, Didwana complex; 5, Budha Pushkar; 6, Luni Valley complex; 7, Hokra; 8, Samnapur; 9, Belan Valley complex; Io, Middle Son Valley complex; I , Beas-Berach complex; I2, Upper Son Valley complex; I3, Bhimbetka; I4, Adamgarh; I 5, Singhbhum; i6, Hiran Valley complex; 17, Patne; I8, Bora; I9, Ramayogi Agraharam; 20, Konkan complex; 21, Shorapur Doab complex; 22, Kaladgi Basin complex; 23, Kurnool Caves; 24, Attirampakkam; 25, Badatomba-lena; 26, Fa Hien Cave; 27, Site 50; 28, Site 49 .

200I). Extreme aridity characterizes the Thar Desert during the Last Glacial Maximum, a time period that saw the weakening of the southwest monsoon (Deotare et al. 2004). The effects of climatic oscillations on population size and dispersal within South Asia are likely to have been as dramatic as those seen elsewhere (Forster 2004).
Tectonic and volcanic events may have had significant effects on Later Pleistocene hominin populations. Recent research indicates that the Ganga Plain of northern India remained tectonically active throughout the last 80,000 years (Srivastava et al. 2003). Tephra deposits from the Toba supereruption, ca. 75,000 years ago, have been re- 
ported from river valleys within peninsular India (Westgate et al. I998). It has been proposed that this volcanic event caused paleoenvironmental changes and a major genetic bottleneck of hominin populations in the Late Pleistocene, resulting in population-level extinctions (Ambrose 1998). The effects of the Toba supereruption on hominin populations in India are currently being examined through ongoing field studies in the Kurnool District.

Climatic changes during the Later Pleistocene have significant implications for understanding the size and isolation of hominin populations and changes in adaptive strategies. The fragmentation of viable ecological niches and the resulting isolation of populations from one another must have affected the transmission of cultural and technological practices. At certain time periods, including oxygen isotope stage 4 , it is likely that the Thar Desert, the Himalayas, and possibly the Ganges Delta would have provided barriers to hominin population movement (Field and Lahr 2005, Field, Petraglia, and Lahr 2005). Not only would this have affected the transmission of cultural information within the region but also it would have reduced the number of routes into the region for populations dispersing from elsewhere.

\section{Current State of Knowledge about the South Asian Record}

Though the fossil record of the Indian subcontinent is sparse, two hominin species are known from the Later Pleistocene. A partial cranium recovered from the Narmada River Basin, India, and dated by faunal correlation to ca. 300,000-250,000 years ago (Kennedy 2000) is currently attributed to $H$. heidelbergensis (Rightmire 200I). Although the Narmada calvarium is associated with Late Acheulean artifacts, no hominin remains have been found with Middle Paleolithic industries. Excavations in Sri Lanka have recovered remains of $H$. sapiens dated to ca. 3 I,000 years ago at Fa Hien Cave and ca. 28,500 years ago at Batadomba-lena (Deraniyagala I992). The association of these remains with microlithic industries provides the earliest conclusive evidence for humans that were both anatomically and behaviorally modern within the Indian subcontinent. Terminal Pleistocene to midHolocene human remains have been discovered throughout South Asia, providing a rich source of information on paleodemography and bio-cultural adaptations (Kennedy 2000).

Phylogenetic patterns from both mitochondrial DNA and the Y chromosome support the colonization of South Asia by modern humans originating in Africa (Kivisild et al. I999a, I999b, 2003; Metspalu et al. 2004; Quintana-Murci et al. I999). As in the majority of mitochondrial DNA variation outside of Africa, South Asian lineages belong to haplogroups $\mathrm{M}$ and $\mathrm{N}$ (groups $\mathrm{U}$ and $\mathrm{R}$ being major subclades of $N$ ), thought to be descended from the $\mathrm{L}_{3}$ haplogroup that arose in Africa ca. 85,000 years ago (Forster and Matsumura 2005, Metspalu et al.
2004). While coalescence dates for haplogroup $M$, which is shared by most non-European populations, average between 73,000 and 55,000 years before present (Kivisild et al. 2000), the geographic origin of the $M$ lineages remains uncertain. The high numbers of India-specific $M$ lineages have led to the suggestion of a Southwest Asian origin (e.g., Richards et al. 2003; Roychoudhury et al. 2000, 200I), although the presence of the MI lineage in some African populations means that an African origin cannot be rejected (Metspalu et al. 2004). Currently it is unclear whether the African Mi lineage represents an ancestral $M$ population or a backward migration. The fact that African M is nearly exclusively found in AfroAsiatic-speakers may suggest a younger presence in Africa (Forster 2004). These issues illustrate some of the difficulties in reconstructing past population movements from the genetic data. Understanding the location of the origin of haplogroup $M$ is, however, crucial to dating the initial dispersal of anatomically modern humans from Africa.

A number of mtDNA lineages (specifically $\mathrm{U}_{2} \mathrm{i}, \mathrm{M}_{2}$, and R5) share coalescence dates of 50,000-70,000 years ago (Kivisild et al. 2000, Metspalu et al. 2004) and may represent an India-specific subclade related to the initial dispersal of modern humans into the peninsula. Such early coalescence dates are supported by those recently obtained for the Andamanese $\mathrm{M}_{3} \mathrm{I}$ and $\mathrm{M}_{32}$ and Malaysian M2I and M22 lineages (Macaulay et al. 2005, Thangaraj et al. 2005) and may support the possibility that modern humans arrived in South Asia during the Middle Paleolithic. Coalescence dates can give only upper estimates for the timing of such dispersals, as the dispersing population may have contained DNA sequences that had already diverged (Nei and Kumar 2000). Strictly speaking, the initial dispersal of modern humans into South Asia may have occurred at any point within the past 70,000 years. Crucially, however, such early coalescence dates raise the possibility that the earliest Homo sapiens fossils recovered from the region may not have been the first anatomically modern humans to have reached the subcontinent. Given the lack of any fossils from the Indian subcontinent that date to between 250,000 and 31,000 years ago, the use of the early fossils from Sri Lanka as evidence for a definitive date for such a dispersal is a misuse of the paleoanthropological record. The dates of the Sri Lanka fossils provide the latest date for the colonization of the region by $H$. sapiens.

Whatever the timing of the dispersal of anatomically modern populations into the subcontinent, the route or routes of this population movement remain controversial (Forster and Matsumura 2005). The great time depths apparent in the Andamanese and Malaysian mtDNA have been argued to support the rapid colonization of the region as part of a southern, coastal route to Australia (Endicott et al. 2003b, Macaulay et al. 2005, Thangaraj et al. 2005), though some of this evidence has been disputed (Cordaux and Stoneking 2003). The phylogeography of mtDNA haplogroups has also been argued to support a southern, coastal route to South Asia (Metspalu et al. 2004). Genetic research has indicated dispersals 
James and petraglia Modern Human Origins $\mid$ S7

from the Indian subcontinent towards Southeast Asia (Majumder 200I, Roychoudhury et al. 2000). A much later, terminal-Pleistocene-to-early-Holocene dispersal from South Asia to Australia has been inferred from the analysis of Y-chromosome data (Redd et al. 2002). It has been suggested that a single dispersal event and hence Asian origins for the initial modern-human colonization of Europe is the most parsimonious explanation for the majority of the genetic evidence. Some aspects of the $\mathrm{Y}$ chromosome and mitochondrial genome may suggest a later "Upper Paleolithic" dispersal to Europe via the Levant, but genetic support for an earlier northern route to Europe seems to be lacking (Kivisild et al. 2000, Metspalu et al. 2004). The contradiction between the most parsimonious explanation for the genetic evidence and that for the morphometric evidence is interesting and may suggest that further work is needed for an understanding of the correlation between phenotypic and genetic change with regard to modern human diversity.

Proponents of the southern dispersal route have argued for a rapid initial dispersal around the South Asian coastline (e.g., Oppenheimer 2003), but the mitochondrial DNA evidence suggests expansions of modern human populations within South Asia close to its initial colonization (Kivisild et al. I999b, Metspalu et al. 2004). A further demographic expansion is suggested by the coalescence of a number of India-specific $M$ lineages to 20,000-30,000 years ago (Kivisild et al. I999b, Metspalu et al. 2004) and may be related to other demographic expansions within the Old World and the more stable climate of oxygen isotope stage 3 (Forster 2004). Intriguingly, recent work has indicated a genetic continuum between the Near East and India coalescence-dated to between 50,000 and 30,000 years ago. By 20,000 years ago the window of this continuum had closed, perhaps representing the isolation of populations due to the increased aridity of western India and Iran as the Last Glacial Maximum approached (Metspalu et al. 2004).

Archaeology offers insights into the population history of South Asia, as more than a century of research has revealed a rich Later Pleistocene record. While most attention has been focused on the Lower Paleolithic of the region (e.g., Petraglia 200I), the Later Pleistocene record is abundant, revealing information about hominin adaptations through time (e.g., Misra I989, 200I; Paddayya I984). Later Pleistocene sites are known mainly from surface surveys (e.g., Gudzer I980, Joshi et al. I979-80), some of them providing vital information on settlement patterns and landscape use (e.g., Pappu and Deo I994, Raju I 988). Several significant excavations of Later Pleistocene sites have provided important information on chronology and changes in paleoenvironments, settlement, and technology (e.g., Joshi I 978; Misra I 985, I989). Serious methodological problems do pervade archaeological investigations in South Asia, where little attention has been paid to high-precision fieldwork and artifact analyses. Unfortunately, most studies have been conducted without consideration of the role of postdepositional processes in contributing to site formation, and few studies have examined the spatial distribution of material remains to identify hominin activities across living surfaces (Petraglia I995). Archaeological investigations carried out in the Kortallayar Basin are a notable exception (Pappu I999, 200Ia, b; Pappu et al. 2003).

\section{Chronology}

Dating by relative and absolute methods has helped clarify the development of the series of different industrial complexes produced during the Later Pleistocene. While some dates are available, the precise boundaries of the lithic industries are not well known. The I6R Dune in Rajasthan supplies valuable information about the dating of archaeological assemblages (fig. 2). Thermoluminescence, uranium-series, and radiocarbon dates have been gathered from a I9-meter sequence. Here a typologically nondiagnostic sample of artifacts has been dated to $>390,000$ years ago. Archaeological assemblages interpreted as Middle Paleolithic industries are dated to ca. I 50,000 years ago (fig. 3), whereas those identified as Upper Paleolithic are dated to 26,2 Io years ago (Misra I995a).

Most other dates are from single samples or from contexts that are not part of long stratigraphic profiles. Assemblages identified as Middle Paleolithic have been difficult to date on account of their contexts and the limitations of the chosen chronometric methods. A Middle Paleolithic scraper-based industry from Patpara in the Middle Son Valley is dated to < I03,000 years ago (Blumenschine, Brandt, and Clark I983, Williams and Clarke I995), while dates of 75,000 and $>60,000$ years ago are associated with artifacts recovered from Samnapur (Narmada Valley) and Balotra (Luni River valley) (Mishra et al. I999, Misra et al. I990). The dating of miolites in the Hiran Valley places assemblages classed as Middle Paleolithic at 69,000-56,000 years ago (Baskaran et al. I986). The earliest assemblage classified as Upper Paleolithic is currently Site 55, Pakistan, where the loess overlying the occupational horizon has been dated to ca. 45,000 years before present (Dennell et al. I992).

In India, a number of assemblages identified as Upper Paleolithic have been dated to between 40,000 and 20,000 years ago, including those from the sites of Mehtakheri, Inamgoan, Chandrasal, Dharamouri, and Nandipalle (Mishra I 995). The microlithic assemblages from Batadomba-lena, Sri Lanka, date from 28,500 years ago, and two other microlithic assemblages from Sri Lanka, those of Site 49 and Site 50, date to 28,000 years before present (Deraniyagala I992). Overall, there is a paucity of chronometric information, especially in comparison with other regions (e.g., Western Europe), which have thousands of available dates. Moreover, there is little confidence in some of the chronometric results, as dates have not been verified by independent methods or by robust sampling procedures.

Relative sequences of assemblages have been obtained from stratigraphic contexts in individual sites and across landforms such as river valleys. Excavated sites in the Thar Desert (Singi Talav and Indola-ki-Dhani) (Misra et 


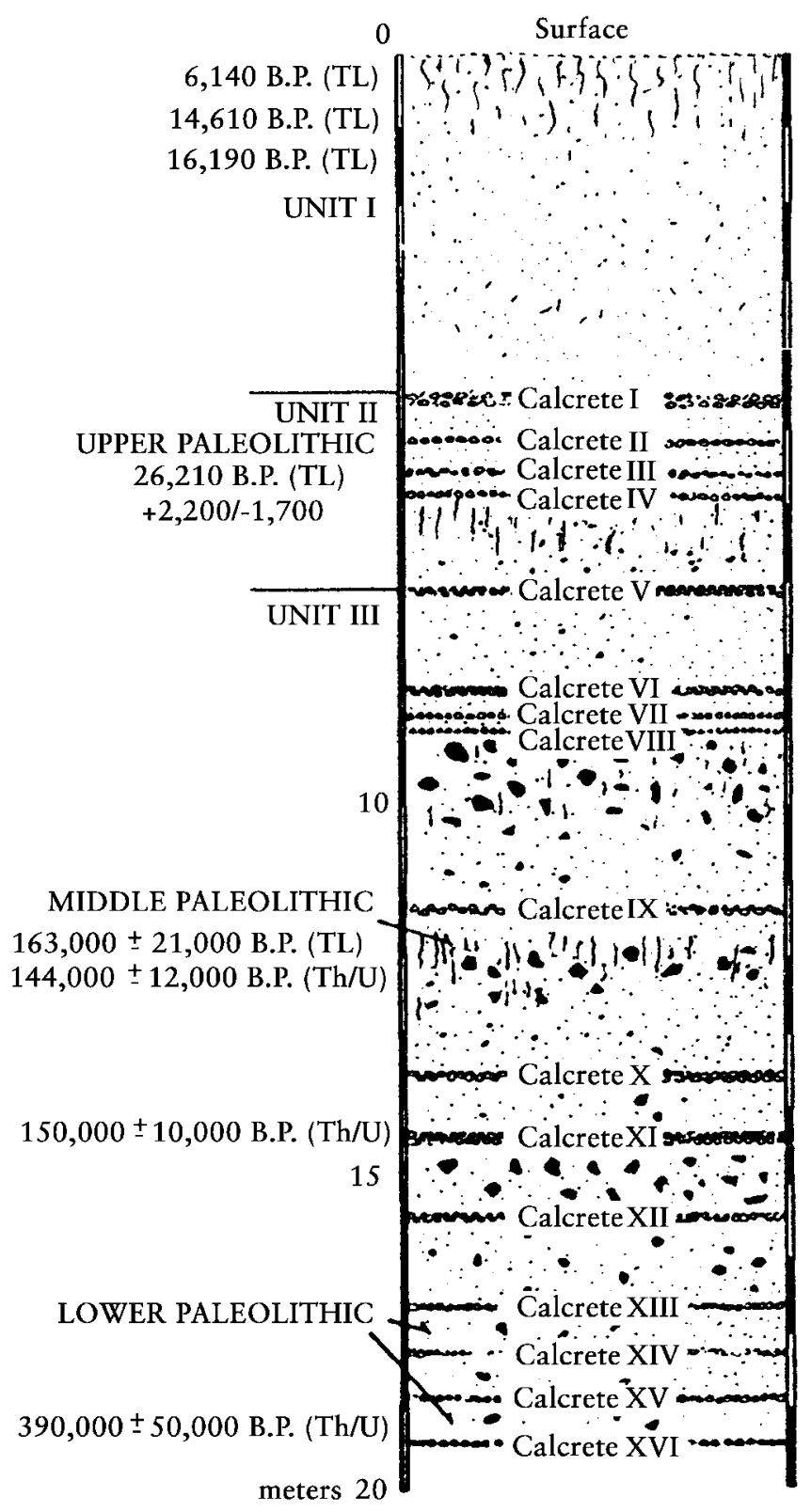

FIG. 2. The stratigraphy of the I6R Dune, Thar Desert, Rajasthan, India. The I9-meter-deep profile shows a sequence of archaeological deposits and chronometric dates (after Misra I989:fig. Io).

al. I982) and in the Kaladgi Basin (Lakhmapur East and West) (Petraglia, Schuldenrein, and Korisettar 2003) indicate the presence of early Middle Paleolithic industries overlying the Late Acheulean. Initial work in the Kortallayar Basin has produced a relative sequence of sites from the Acheulean to Upper Paleolithic (e.g., Pappu 200Ia). A relative sequence of excavated Acheulean-toMesolithic sites has been compiled for the Middle Son and Belan Valleys (Clark and Williams I990, Sharma and Clark I983). The most important site sequence is that of Bhimbetka III F-23, where 3.8 meters of excavated deposit have produced artifacts from the Late Acheulean to the Mesolithic (Misra I985). The excavated sequence at Patne contains late Middle Paleolithic-to-Mesolithic assemblages in a ro-meter section (Sali I989) (fig. 4).

\section{Later Pleistocene Technology and Industry Characteristics}

South Asian hominin populations of the Later Pleistocene produced two distinct stone tool industries. These assemblages were originally classified as Middle Stone Age (MSA) and Late Stone Age (LSA) (e.g., Allchin I959; Sankalia I964a, bl, apparently as a consequence of their technological affinity with African assemblages. Although these assemblages were later termed Middle Paleolithic and Upper Paleolithic, the Upper Paleolithic
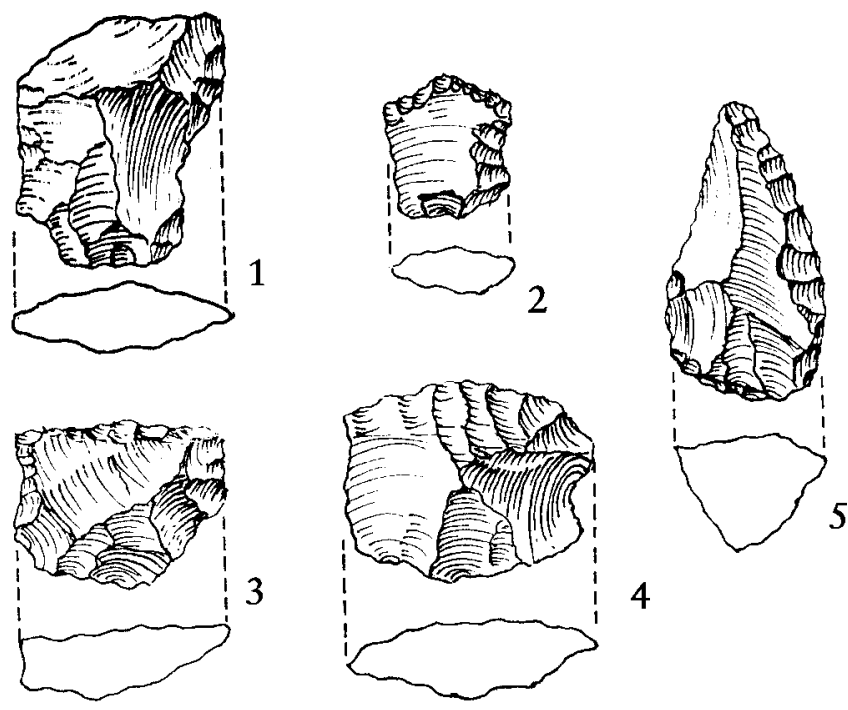

4
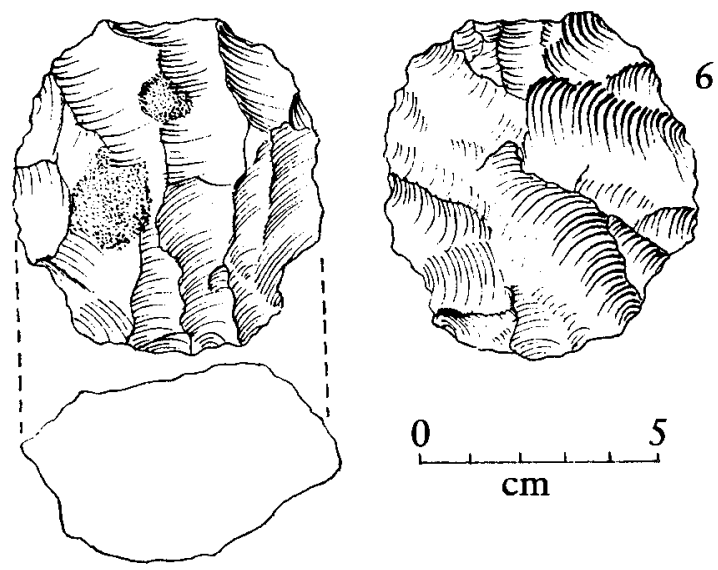

FIG. 3. Middle Paleolithic artifacts from the $I 6 R$ Dune, Thar Desert (after Misra I995b: figs. I6 and I7). I-4, scrapers; 5, point; 6, core. 


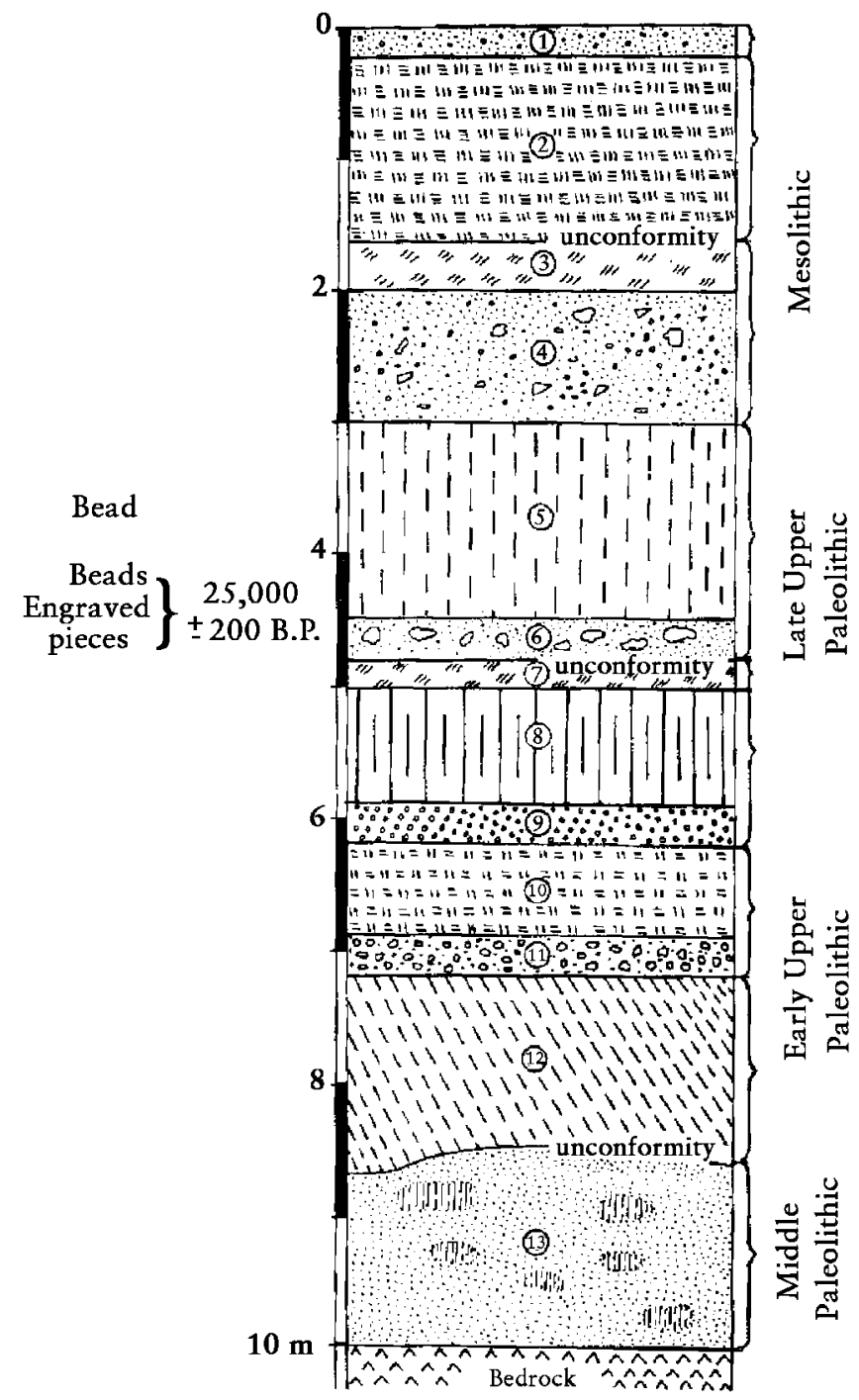

FIG. 4. The Late Pleistocene stratigraphic profile of Patne, Maharashtra, India, showing locations of beads and radiocarbon date (after Sali I989:fig. II).

designation remains problematic, as, despite claims of close similarities, it is not coincident with its European counterpart. Flake-based artifact assemblages consisting of prepared cores, retouched flakes, and diminutive bifaces generally characterize the Middle Paleolithic of the subcontinent (e.g., Jayaswal I978, Paddayya I984). Following the Middle Paleolithic, blade-based and microlithic industries appear to become increasingly important. The so-called Upper Paleolithic industries are variable in composition but demonstrate an increase in the production of burins and backed tools at some sites (Murty I979, Paddayya I984). There is considerable temporal and spatial variation in the appearance and frequency of these flake- and blade-based industries, and the technological shift does not appear to have been rapid.

\section{The Middle Paleolithic}

The majority of South Asian Middle Paleolithic industries are produced on flakes struck from prepared cores. Technological studies in the Kaladgi Basin (fig. 5) suggest that the use of prepared-core methods developed from the preceding Acheulean (Petraglia, Schuldenrein, and Korisettar 2003). It therefore forms part of a growing body of global evidence (e.g., Petraglia and Alsharekh 2003, White and Ashton 2003) which supports the local, convergent evolution of prepared-core technology. During the Middle Paleolithic there does not appear to be a single or favored technique of core preparation throughout the subcontinent. "Levallois" and "discoidal" techniques are the most commonly identified, but other core types have been described (e.g., "cylindrical") (Misra I967, I968). Technological diversity is also indicated by the presence of unprepared cores in Middle Paleolithic assemblages. Numerous sites show evidence of the use of a wide range of core reduction techniques, including Hajiakheri (Misra I968), Lahchura 2 (Pant I982), and Attirampakkam (Pappu 200I $a$ ). Flakes may also be derived from natural spalls and from amorphous cores (Pappu 200I $a$ ). Many of these coretype designations have yet to be supported by detailed
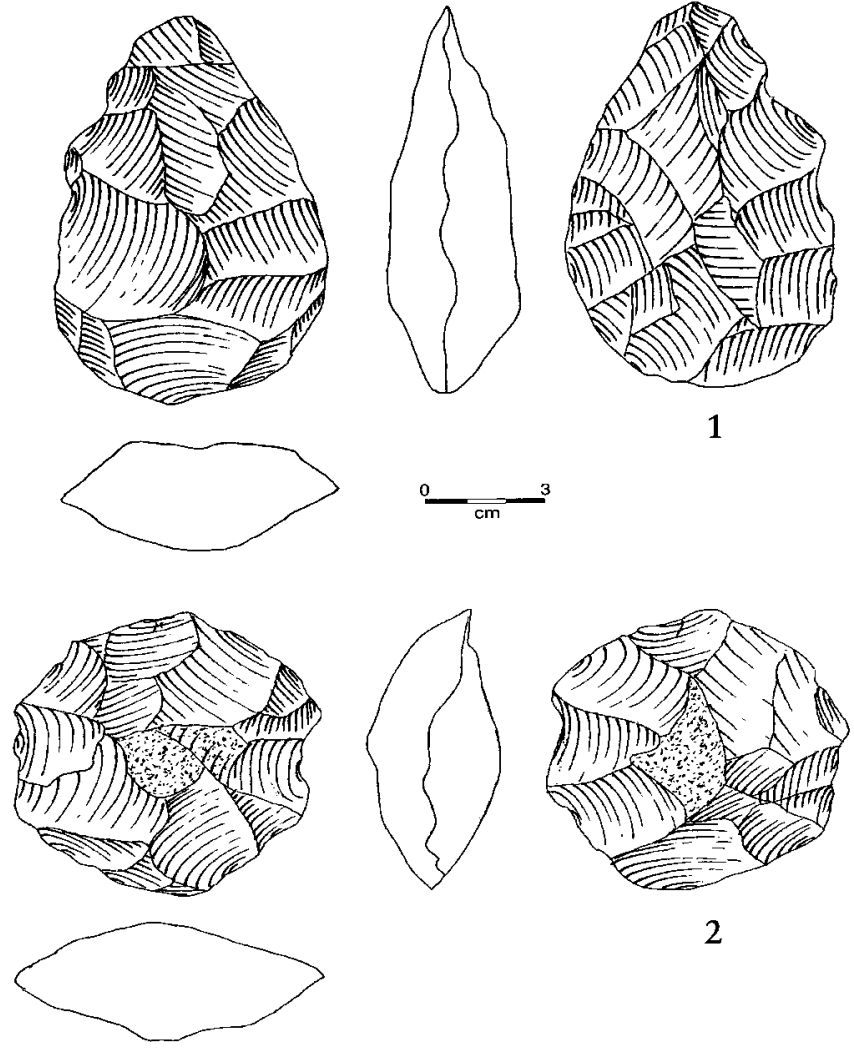

2
FIG. 5. Early Middle Paleolithic artifacts from the Kaladgi Basin, Karnataka, India. I, diminutive biface; 2, prepared flake core (after Petraglia, Schuldenrein, and Korisettar 2003:figs. 8, 9). 

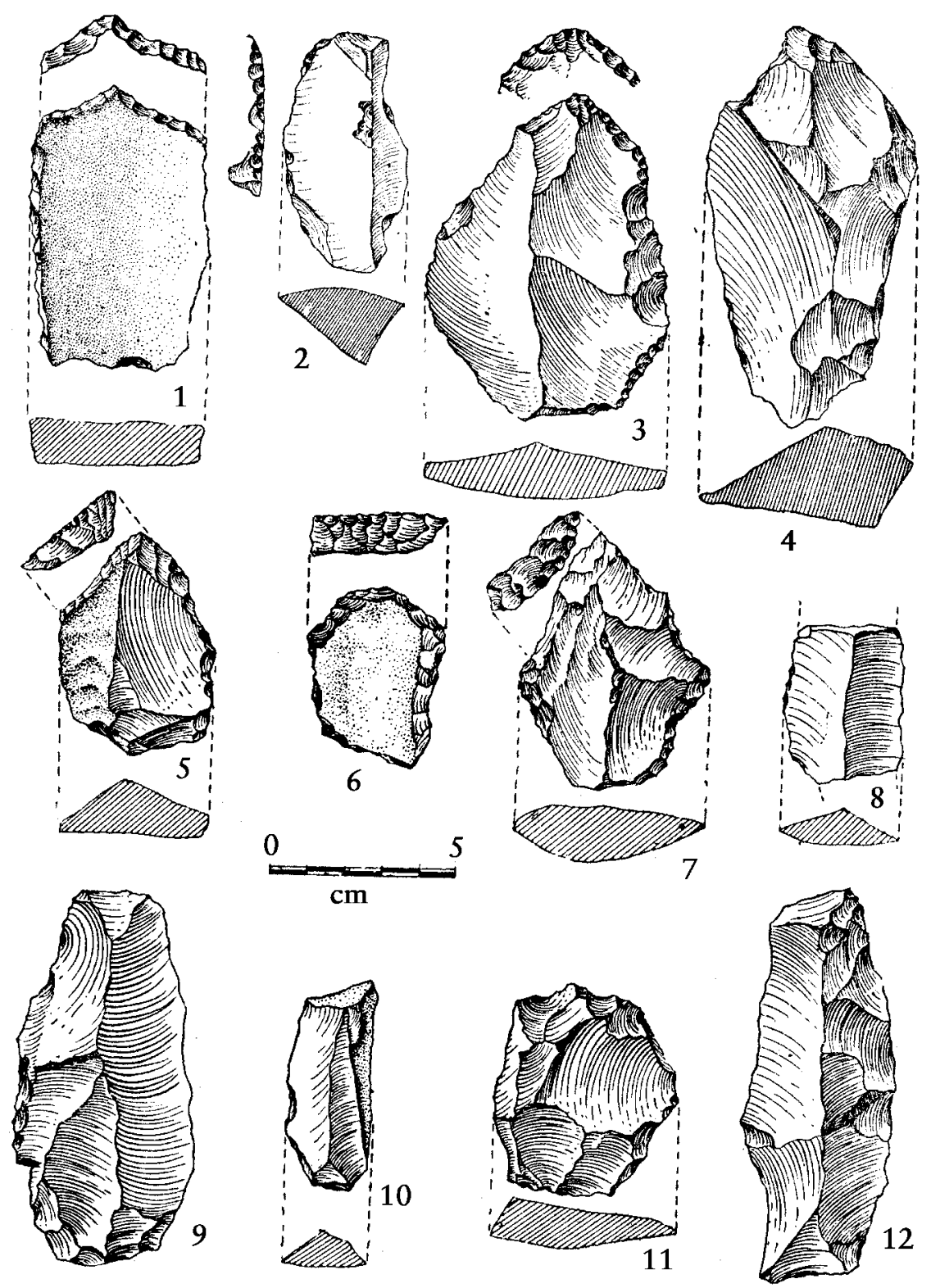

Fig. 6. Middle Paleolithic artifacts from Bhimbetka III F-23, Madhya Pradesh, India (after Misra I985:fig 4). I-3, 5-7, scrapers; 8-IO, I 2, blades; 4, I I, flakes.

reduction-sequence analysis, but studies have suggested that there is variability in core reduction sequences within the region (Jayaswal 1978). The frequency of different methods of core preparation shows spatial variation across the subcontinent (James 2003). In the river valleys of Uttar Pradesh (Pant I982) and the Kortallayar Basin (Pappu 200Ia) the Levallois technique dominates, but in the Wagan and Kadmali River basins (Misra I967, I968) the use of the discoidal technique is far more common.

Middle Paleolithic industries from Sri Lanka and Nepal appear to differ from those recovered in other parts of South Asia. Evidence for premicrolithic industries in
Sri Lanka is sparse (Deraniyagala I992). In Nepal, the site of Arjun 3 (Dang-Deokhuri Valley) has produced a Levallois-based industry containing scrapers, points, and blades that is older than ca. 30,000 years (Corvinus I994, I995, 2002). This industry is succeeded by industries consisting of unifacial choppers produced on large cobbles. These later industries lack any evidence for core preparation (Corvinus I994).

Excluding the later sites in the Nepalese sequence, there appears to be a notable blade and flake-blade component to the South Asian Middle Paleolithic. Blade and flake-blade cores are documented at localities such as 

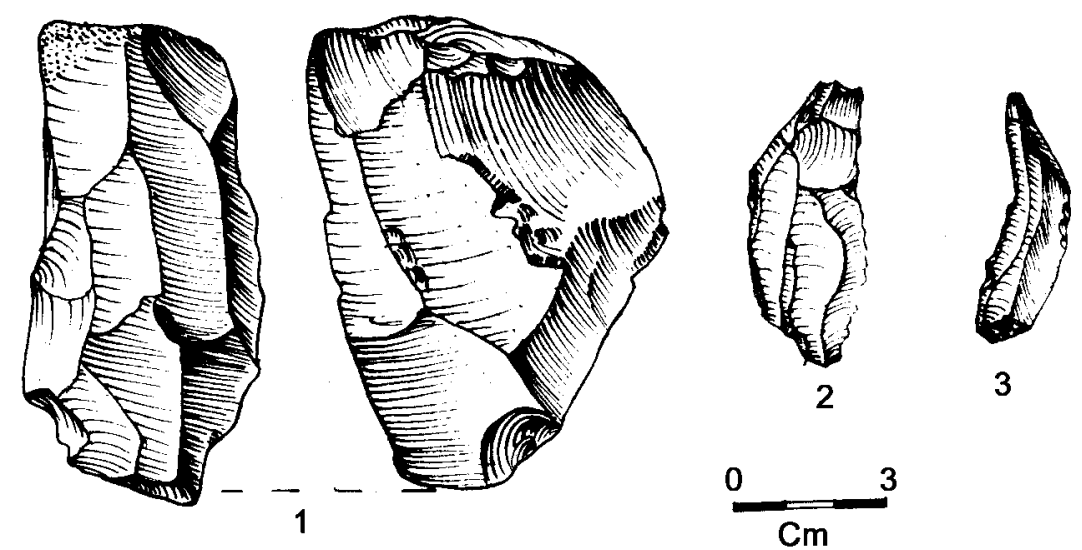

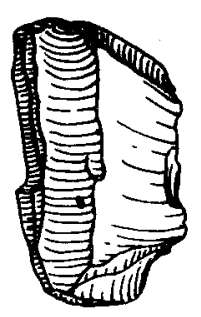

4

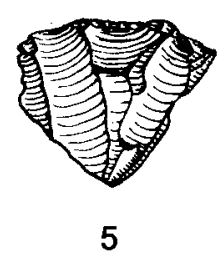

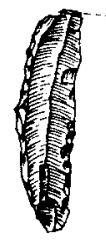

6

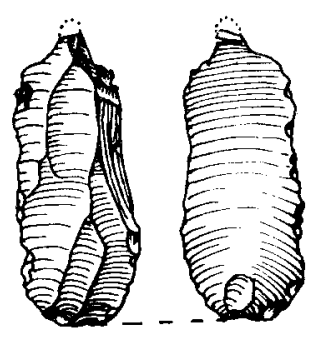

7

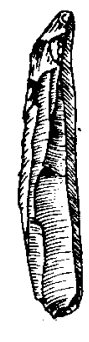

8

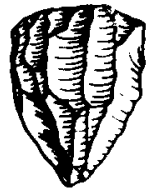

9

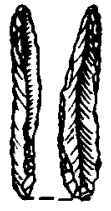

10

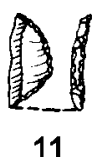

11

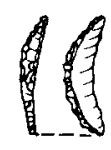

12

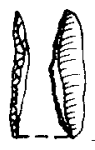

13

FIG. 7. Technological transition of stone tool assemblages at Patne. Top, advanced Middle Paleolithic (phase I); middle, Early Upper Paleolithic (phase IIB); bottom, Late Upper Paleolithic (phase IID) (after Sali I989:figs. I9, 2I, 23). I, 4, 5, 9, blade cores; 2, 3, 7, I0, retouched blades; 6, backed blade; 8, blade; I I-I3, lunates.

Patpara (Blumenschine, Brandt, and Clark 1983), the Kortallayar Basin (Pappu 200I $a, b$ ), and Bhimbetka (Misra I985) (fig. 6). The unidirectional cores recovered from the Thar Desert region at sites such as Hokra I-a and Gurha (Allchin, Goudie, and Hegde 1978) appear to indicate the production of blades as blanks. The blades are not struck from prismatic cores but appear to be the intended product. Typically a single flake is removed from a core, providing a platform from which a small number of blades and flakes can be struck. The cores do not appear to be systematically reduced, with only a small number of flakes and blades being removed. The blades and bladelike flakes represent the majority of the "blanks" struck from the core, suggesting that the intention of the cores was to produce narrow, elongated flakes. Given the paucity of chronological data for the period, determining changes in core reduction strategies over time is difficult. Initial comparisons suggest, however, that the technique may have become more devel- oped as the Middle Paleolithic progressed. Cores from the "advanced" Middle Paleolithic assemblage at Patne indicate a similar process of blade production. They differ from those of earlier sites by reduction intensity, with more blades (and indeed flakes) removed from each core (fig. 7). While they typically form a small proportion of total blank production, the blades and bladelike flakes produced by these methods are used in the manufacture of a number of finished tools, including various scraper forms. Such blade-based tools are noted from the Middle Paleolithic industries of Chancha Baluch (Allchin, Goudie, and Hegde I978), the Panchmahals (Sonawane I984), the Godavari Valley (Joshi et al. I979-80), Bhagi Mohari (Paddayya I982-83), and other localities.

In terms of assemblage composition, the South Asian Middle Paleolithic exhibits variation in the presence or absence of different tool types and their relative frequencies (James 2003). While scrapers are the dominant tool form in much of the Indian subcontinent, there are 
sites in, for example, the Kurnool District and the Gunjana Valley where points have been identified as increasingly important (Raju I988). This seems to fit into a general pattern of variation in which points are much less common in northwestern and north-central regions than they are in the southeast. Points, for example, are particularly poorly represented at Bhimbetka III F-23 (Misra I985), Patpara (Blumenschine, Brandt, and Clark I983), and the Upper Son (Ahmed I984). Similarly variable is the presence of diminutive handaxes within Middle Paleolithic assemblages, though they are distributed throughout the subcontinent. No clear geographical patterning can be observed in their distribution, and the chronological resolution is currently lacking to test the assumption that they are present only in early Middle Paleolithic assemblages (Paddayya I984). Tool types identified as "knives" and "borers" are rarer in Middle Paleolithic assemblages, though their presence in Bhimbetka indicates that they are a component of at least some Middle Paleolithic industries (Misra I985). Denticulates, notches, and, rarely, burins have been noted from a small number of sites, including Parsidhia (Uttar Pradesh) (Pant I 982), Mangalpura (Didwana) (Misra et al. I982), and Bhimbetka (Misra I985). Chronological change may explain some of the variation in the occurrence of these rarer tool forms. Polyhedrons are found in earlier Middle Paleolithic sites, such as Indola-ki-Dhani and Singi Talav, Didwana (Misra et al. I982), but are lacking from the assemblage in Patpara (Blumenschine, Brandt, and Clark I983). Tanged points, though rare, have been noted from a number of assemblages, including the Upper Son Valley (Ahmed I984) and Ramayogi Agraharam (Rath, Thimma Reddy, and Vijaya Prakash I997). Formalized retouch toward the production of particular tool types is not a general characteristic, and therefore the use of a generalized Middle Paleolithic terminology is appropriate.

\section{The Late Paleolithic}

From approximately 45,00o years ago, increases in blade production and variability in assemblage composition characterize the South Asian archaeological record. Traditionally classified as Upper Paleolithic and divided into flake-blade, blade-based, and blade and burin industries (Murty I979), such assemblages are fewer than those identified as belonging to the preceding Middle Paleolithic. In addition, South Asian microlithic industries, often referred to as "Mesolithic," date to 28,500 years ago, indicating that they may be part of a diverse Later Pleistocene package. We term this package the Late Paleolithic in order to emphasize its differences from both the LSA of Africa and the Upper Paleolithic of Europe.

Large, thick blades (Paddayya I984:353) associated with scrapers, borers, and points produced mainly on flakes characterize industries such as those from Singhbum and Watru Abri (Murty I979, Paddayya I984). Scrapers on flakes are associated with small backed blades at the excavated site of Mehtakheri (Mishra n.d.). Both macro- and microblades and cores are reported from Visadi (Allchin I973). At Site 55, Pakistan, flake-blades are associated with blades small enough to be classed as microliths (Dennell et al. I992). In contrast, the Sri Lankan sites of Batadomba-lena, Site 50, and Site 49, dating from 28,500 years ago, contain industries that are based on the production of geometric microliths (Deraniyagala I992) (fig. 8). In sites such as Patne, geometric microlith technology develops from an industry characterized by a few backed blades and burins (Sali I989). However, Patne's microlithic industries date to ca. 24,500 years ago, slightly postdating their early appearance in Sri Lanka. In addition, contemporary sites from the Indian subcontinent such as Inamgaon (ca. 25,000-2 I, 000 years ago) have produced industries consisting of scrapers, blades, points, and fluted cores in which the production of backed blades is minimal (Murty I979). With the exception of the geometric microliths, the standardization of retouched artifact forms is not comparable to that seen in the Aurignacian and later industries of Upper Paleolithic Europe.

Research is continuing into the differences in core reduction strategies that may characterize these different industries, but initial comparisons between cores within the Patne sequence suggests that there is no sudden shift to "classic" prismatic cores at the onset of the Late Paleolithic. Cores from the early "Upper Paleolithic" strata are comparable in technique to those from the "advanced Middle Paleolithic" from the same site but exhibit a greater number of flake and blade removals (fig. 7). Prismatic blade cores are present in the Late Paleolithic assemblages from Patne and increasingly dominate the assemblages as the period progresses. These prismatic cores are small and seem to have been used in the production of blades, microlithic blades, and bladelets. It is interesting that these levels also include geometric microliths such as lunates and triangles.

There is no clear sequence of industrial subdivisions within the Late Paleolithic of South Asia. There is, however, contemporaneity between flake- and blade-based technology and microlithic industries after ca. 28,500 years ago. The microlithic industries in South Asia are earlier than those seen in Europe, though they postdate the appearance of microlithic technology in Africa. At the moment, however, the finds at sites such as Patne and the presence of microliths in other Late Paleolithic assemblages from the subcontinent suggest that at least some of these early microlithic industries developed regionally rather than resulting from a dispersal from elsewhere. The similarity in core reduction techniques between the Middle and Late Paleolithic industries at Patne is intriguing. Transitional Middle to Late Paleolithic industries have been reported at sites such as Chancha Baluch (Allchin, Goudie, and Hegde I 978). This evidence suggests that at least some Late Paleolithic industries developed from the Middle Paleolithic. 

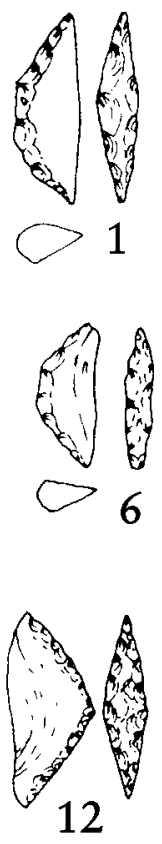
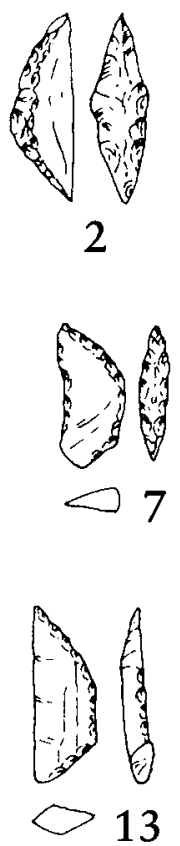
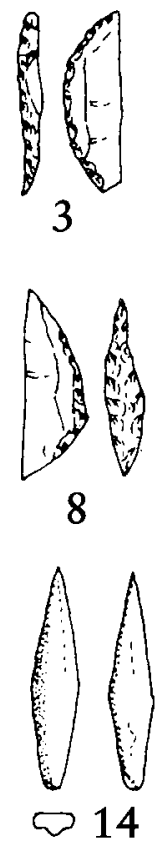
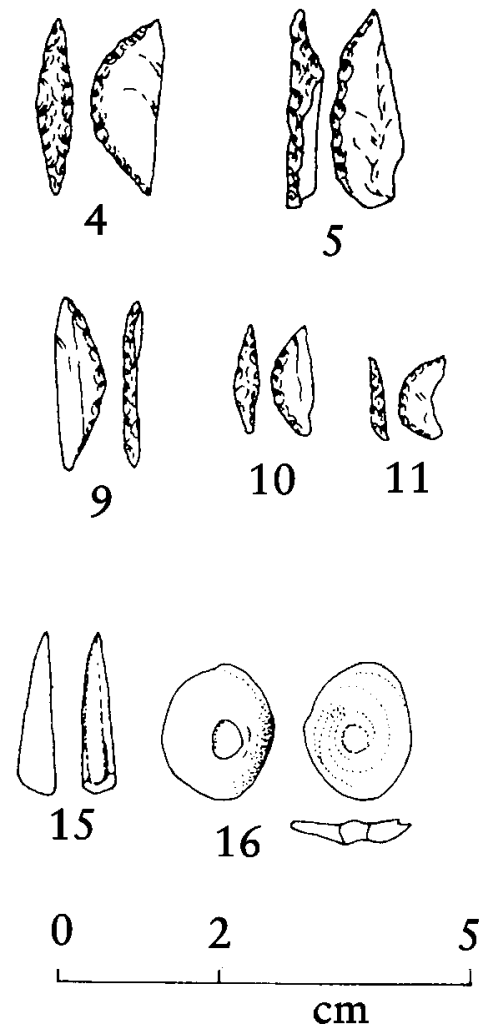

FIG. 8. Microlithic artifacts from Sri Lanka (after Deraniyagala I992:fig. 59). I-I3, geometric microliths; I4, I5, bone points; I6, bead.

\section{Symbolism, Structures, and Modern Human Behavior}

The majority of the evidence for modern behaviors and symbolism in South Asia dates to no earlier than 28,500 years ago, although there are several notable exceptions. There is possible evidence for early ochre use in the form of a number of fragments of haematite in Acheulean sites in the Hunsgi Valley, including a striated "crayon" (Bednarik I990, Paddayya I982). The early use of ochre within South Asia may not necessarily be symbolic. Another claim for nonutilitarian use of materials are six quartz crystals associated with Acheulean materials at Singi Talav (d'Errico, Gaillard, and Misra I989). Though petroglyphs have been identified on cave and rockshelter walls and boulders, including a cupule and groove on a boulder in Acheulean levels of Auditorium Cave, Bhimbetka (Bednarik 2003, Kumar I996), their interpretation as some of the earliest rock art remains controversial.

Although the earliest evidence for symbolism is sparse, it is clear that by the terminal Pleistocene South Asian populations were selecting and using various materials to manufacture objects. Bone tools have been recovered from a number of Sri Lankan microlithic contexts, of which the earliest is the 28,500-year-old assemblage at Batadomba-lena (Deraniyagala I992).
Though bone artifacts, including possible pendants, have been reported from the Late Paleolithic contexts of the Kurnool region (Murty and Reddy I975, Thimma Reddy I977), the artifactual nature of some of these objects has been called into question (Petraglia I995). A number of Later Pleistocene sites are associated with ostrich-eggshell fragments (Kumar et al. I988, I990). The earliest evidence of adornment is the ostrich-eggshell beads recovered from the 28,500-year-old horizon at Batadombalena (Deraniyagala I992) and the 25,000 \pm 200-year-old strata at Patne (Sali I 989). The same level at Patne also produced a geometrically incised fragment of ostrich eggshell, the earliest deliberate artifact "decoration" from peninsular India (fig. 4). Recent excavations have discovered a Late Paleolithic bead production site in Madhya Pradesh (Mishra, Ota, and Naik 2004). One other possible example of Late Paleolithic art is a carved and polished "goddess" figurine from the Belan Valley of Uttar Pradesh (Misra I977), which has recently been reinterpreted as part of a bone harpoon point (Bednarik 2003). A burial of a late modern human at Bhimbetka contains two ostrich-eggshell beads found near the neck (Bednarik 2003).

Evidence for the deliberate construction of structures is rare in South Asia. The earliest evidence consists of the stone-lined pit and low wall reported from Site 55, 
Pakistan, and dated to 45,00o years ago (Dennell et al. I992). Structures have also been reported from Bhimbetka (Misra 1989). A sandstone platform and curiously patterned rock discovered at the Late Paleolithic site of Baghor I have been interpreted (via the use of ethnographic comparisons) as the earliest "mother goddess" shrine in the subcontinent (Kenoyer et al. I983).

The evidence for symbolic thought and, indeed, for the majority of the traits cited as evidence for modern human behavior is relatively sparse. The population of the region during the Late Paleolithic was clearly capable of explicitly symbolic behavior, leaving little doubt that the populations that produced these artifacts and sites were behaviorally modern, but there is no symbolic revolution of the kind that accompanies the Aurignacian in Europe. While differential survival (and, indeed, recovery) of artifacts may well play a role in the discrepancy, this cannot be the whole story. Given the considerable archaeological research that has occurred in South Asia during the past century, it seems reasonable to argue that the Late Paleolithic of the Indian subcontinent is unique. Despite the current "Upper Paleolithic" label, it is as different from the Upper Paleolithic of Europe as it is from the LSA of Africa.

In sum, modern human behavioral traits such as symbolic thought and the construction of structures appear to date to after ca. 45,000 years ago. A range of novel technologies characterizes the Late Paleolithic, including the manufacture of bone tools and geometric microliths by 28,500 years ago. The technological variability within this period needs to be further investigated, but the evidence suggests a diversification of modern human behaviors during the climatic oscillations of the Terminal Pleistocene. Other technological innovations, such as deliberate blade production, variability in flake reduction strategies, and geographical and chronological variability in the presence of retouched tool types, date to the Middle Paleolithic. The relationship between assemblage composition and resource availability in this period remains to be fully investigated. Chronological, geographical, and possible stylistic variation between lithic assemblages has been interpreted as signifying the presence of behavioral modernity within the MSA of Africa (McBrearty and Brooks 2000). The presence of similar variation within South Asia (James 2003) as well as Europe and the Near East suggests that such behaviors may not be uniquely human. The South Asian evidence for early deliberate blade production is consistent with the growing evidence for blade manufacture by hominin populations other than $H$. sapiens (Bar-Yosef and Kuhn I999). The ability to produce a flexible technology that could be adapted to different ecological niches and tasks (which is presumably what such chronological and geographical variation would represent from an evolutionary perspective) was not limited to early anatomically modern humans. Instead, it formed part of the behavioral repertoire of related species such as the Neanderthals and the archaic hominin populations of South Asia.

\section{Hominin Dispersals}

The evidence of local evolution of prepared-core technology from Late Acheulean assemblages in South Asia is inconsistent with the hypothesis that prepared-core technology arose in Africa and spread to the rest of the world with dispersing Middle Pleistocene populations. While the archaeological evidence from the Indian subcontinent cannot be used to argue that such population dispersals did not occur, if populations (such as H. helmei or early $H$. sapiens) with Middle Paleolithic technologies dispersed toward South Asia from the west (Lahr and Foley I998, 200I) they would have encountered local populations (H. heidelbergensis or an unknown species) using Middle Paleolithic technologies.

A similar local development of technology seems to be indicated when the transition from the late Middle Paleolithic to the Late Paleolithic is considered, at least for some of the assemblages of the subcontinent. Given the date at which this transition appears to have occurred (ca. 45,000-28,500 years ago), it seems logical that the replacement of archaic hominin populations by behaviorally modern $H$. sapiens should be marked by some distinct archaeological signal. Yet the archaeological record currently suggests no abrupt technological changes from the Late Acheulean through to the microlithic industries of the Terminal Pleistocene.

Multiple dispersals of anatomically modern humans from Africa remain the most parsimonious explanation for modern human diversity (e.g., Lahr and Foley I994). H. sapiens colonized Australia at least 45,000-42,000 years ago (e.g., O'Connell and Allen 2004) and possibly earlier (e.g., Bowler et al. 2003). Archaeologists have also begun to document coastal occupations along the African (Walter et al. 2000) and Arabian (Petraglia and Alsharekh 2000) coasts, and, as indicated, South Asia has coastal and near-coastal sites that may be related to such dispersal events. This evidence increases the plausibility of the hypothesized dispersal of modern human populations from Africa and the initial colonization of South Asia and Australia via a "southern" or "coastal" route (e.g., Cann 200I, Lahr and Foley I994, Stringer 2000). The genetic evidence is consistent with such an early dispersal into South Asia, though it cannot directly support it (e.g., Kivisild et al. 2003, Quintana-Murci et al. 200I, Redd and Stoneking I999). Our hypothesis is that this initial dispersal reached South Asia during the Middle Paleolithic. Given that the earliest modern humans outside of Africa, at Qafzeh and Skhūl Caves in the Levant, were undoubtedly using a Middle Paleolithic technology, it is perhaps not surprising that the archaeological signal for such a dispersal is difficult to detect. Given the large size of the landmass and the use of similar technology, it is possible that the replacement event took longer in South Asia than elsewhere.

The Later Pleistocene archaeological record of the Indian subcontinent indicates increasing technological diversity. A number of innovations occur in the Later Pleistocene, such as the shift to prepared-core technology, an 
increasing dependence on blade production, microliths, specialized tools, and self-adornment, but these appear gradually and sporadically. They do not provide a "marker" for the dispersal of anatomically modern humans. There is no "Upper Paleolithic revolution" like that seen in Europe (e.g., Mellars 2005) or even a clear change in technology coincident with the arrival of modern humans like that seen in East Asia (Gao and Norton 2002). The timing of some of these behavioral changes does, however, correspond with genetic evidence of demographic expansions in South Asia. The first production of explicitly symbolic artifacts (i.e., beads and "art"), the use of bone, and the first microlithic assemblages appear between 30,000 and 20,000 years ago, coinciding with a major expansion of human populations in the Indian subcontinent (Kivisild et al. I999b).

\section{Conclusion}

As currently understood, the archaeological record from Later Pleistocene South Asia has much to contribute to our understanding not only of what constitutes the material evidence for behavioral modernity but also of the ways in which culture is transformed by demographic processes. The hominins that occupied South Asia during the Later Pleistocene left behind a technologically diverse archaeological record that undoubtedly represents a palimpsest of different, flexible adaptive strategies to variable ecological niches. Evidence for the early intentional production of blades, early microlithic industries, and technology that varies over both time and space provides an intriguing glimpse of the way in which populations coped with fluctuating and often challenging environmental conditions. By the Last Glacial Maximum these populations were undoubtedly both anatomically and behaviorally modern, but the modern human behaviors exhibited were expressed in a way unique to the region. Overt symbolism, in terms of art and selfadornment, is relatively rare and appears relatively late in the record, coincident with evidence for population expansion within the subcontinent. Other aspects of modern behavior, such as structured site use, appear somewhat earlier. The roots of some of the more functional aspects of modern behavior may date to the Middle Paleolithic. These behaviors are also represented in the Levant and in Europe during this period and are plausibly interpreted as something that $H$. sapiens shared with closely related species. Because they are not unique to our species they should not, in our opinion, be considered as markers for behavioral modernity.

Modern humans colonized South Asia as part of an as yet undated expansion of $H$. sapiens from Africa. If the modern behavioral package can be taken as a marker for such dispersals, then the South Asian record should logically show similarities to the archaeological record of Europe rather than to Africa. But in contrast to that of Europe, this record contains no dramatic appearance of a technology such as the Aurignacian that fulfills the "fully modern behavior" criterion and could be linked to the expansion of $H$. sapiens. There is no clear evidence in the South Asian Middle Paleolithic for an early dispersal such as that suggested by some discussants of the genetic data (e.g., Oppenheimer 2003). Yet neither do the Late Paleolithic and the Indian subcontinent's precocious microlithic industries constitute a sudden break. The mosaic of industrial components suggests a gradual shift to intensive blade production, of which the development of microlithic technology seems to be a part. The increasing predominance of blades over flakes is related to the intensification of methods with their technological roots in the Middle Paleolithic. Until the appearance of geometric microliths, the degree of artifact standardization remains debatable, and, indeed, explicitly symbolic artifacts are rare.

A current theme in debates regarding the origin of modern human behavior is that explicit symbolism and complicated resource acquisition (expressed in the archaeological record as multicomponent tools, evidence of food not exploited before, and long-distance exchange networks) are perhaps the best indicators of behavioral modernity (e.g., Henshilwood and Marean 2003). The evidence for complex resource acquisition or at least the date of its origin remains controversial, even within Africa (Klein 2000 contra McBrearty and Brooks 2000), and further research is needed before answers can be ascertained from the South Asian record. Symbolic thought or at least evidence for explicit symbolism appears later in the South Asian record than in Africa or Europe, and when it does it appears gradually. This situation is much more like the African MSA, where Blombos Cave (e.g., Henshilwood et al. 2002, 2004) constitutes the best and some would argue the only evidence for symbolic thought associated with early anatomical moderns, than the sudden explosion that is seen with the arrival of the Aurignacian in Europe. This gradual appearance in South Asia has significant implications for the way we define "behavioral modernity."

If symbolic thought is indeed the best indicator of the presence of a modern brain, then the appearance of explicitly symbolic artifacts should serve as a proxy signal or marker for the arrival of $H$. sapiens in a given region. Such artifacts appeared gradually in Africa because this is where the modern mind likely evolved. The European record, with its sudden technological and symbolic "revolution" (Mellars 2005), represents the dispersal into the region of hominins with fully modern minds. But, as we have seen, the evidence for symbolic thought does not appear suddenly within South Asia. There are two possible reasons that this is the case.

First, it is possible that the members of our species that first colonized South Asia were not behaviorally modern-that they were incapable of fully symbolic thought. If behavioral modernity is indeed the result of a reasonably late neurological change (e.g., Klein 2000), then this is precisely what would be expected if the initial dispersal of modern humans into the area occurred prior to ca. 50,000 years ago. An early dispersal of modern humans into the Indian subcontinent is, in our view, the most parsimonious explanation of the available evi- 
dence, but on its own it cannot explain the eventual presence of behaviorally modern humans in the region. Either more cognitively able members of the same species replaced such initial colonizers after ca. 50,000 years ago (in which case we might expect some kind of archaeological marker) or such genetic/mental change occurred synchronously within $H$. sapiens populations in Africa and South Asia. Both of these explanations appear highly problematic. In our view it makes more sense to see the Middle Paleolithic colonizers of South Asia as both anatomically and cognitively modern.

The second possibility is equally applicable to an early dispersal into South Asia or a later one. Ethnographic studies have indicated that symbolic thought is one of the suite of behaviors that may well be unique to humans, as reflected by our need to create and manipulate identities and our incorporation of material culture into that process (e.g., Hodder I 982). But they also show that this behavior is not always expressed in the same way. To oversimplify, different cultures use different aspects of material culture in identity construction. Symbolic thought and, by extension, modern human behavior are not just represented by art or beads. Thus, while the appearance of such objects in the archaeological record indicates the presence of a modern mind, the lack of such objects cannot be taken to mean the absence of such a mind. The most parsimonious explanation for the absence of a correlation between the arrival of the modern humans in South Asia and the explosion of symbolic thought is that the latter is not being expressed in the form that we are expecting.

If this is indeed the case, the "Upper Paleolithic revolution" in Europe and the sporadic use of overtly symbolic artifacts in MSA Africa and, later, in South Asia are the result of something other than neurological change. Instead, it is probable that they are the result of particular demographic situations. The specific nature of these situations remains to be elaborated, but it is clear that population size plays a role in cultural change. By affecting the relative importance of natural selection or cultural drift, changes in population size will affect changes in material culture (Shennan 2000, 200I). It may well be that signaling identity (whether individual or group) through the use of ornaments or other forms of art is adaptive in situations in which there is competition for resources. But if cultural drift plays a bigger role in determining the contents of material culture (as it may well do in a small population) than natural selection, the behavior may not be expressed or may be expressed in another, less adaptive way (Shennan 2000).

The Later Pleistocene is characterized by climatic oscillations that must have influenced both the skills hominins needed to survive and their population size, but the hominin populations that inhabited South Asia were able to endure them. It is likely that marginal populations were forced to disperse or decrease in size during periods of resource scarcity. Especially harsh conditions may have contributed to the extinction of such populations. Crucially, however, such processes of extinction, growth, and dispersal must be viewed at a population rather than a species level. While climatic change affected population movements within the region, it would also have influenced the likelihood of population movement between South Asia and the rest of the Old World. Such demographic fluctuations were not restricted to South Asia, as the genetic evidence clearly shows (Forster 2004). Given the effect of demographic processes on cultural evolution and innovation, archaeologists have to be careful in selecting the traits considered representative of behavioral modernity. Until we understand how these processes influence material culture, creating a trait list of modern behaviors extrapolated from present-day hunter-gatherers or based on any one regional record is fraught with difficulty. To ascertain what makes modern humans unique from a behavioral perspective we need to understand the cognitive and behavioral capabilities of our closest relatives, including the archaic hominins that inhabited South Asia.

Further high-quality investigations are needed if such hypotheses are to be tested, and it is vital that this research continue not only in Europe and Africa but also in other areas of the world. This synthesis has indicated the enormous potential of South Asia for contributing to investigations into modern human origins and the evolution of behavior and the need to place the fossil, genetic, and archaeological records in a global framework. Ongoing research in South Asia may help to unravel the processes that are part of the modern behavioral package.

\section{Comments}

SOPHIE A. DE BEAUNE

Université Jean-Moulin, Lyon III, and UMR CNRS

704 I "Archéologies et Sciences de I'Antiquité,"

Nanterre, France (sophie.de-beaune@mae.u-paris Io.fr).

2 I VI 05

This is a very interesting and stimulating article. I agree on the whole with the authors' conclusions but would like to express some reservations.

First of all, pointing out that, at sites such as Patne, the industries of the Middle and Upper Paleolithic display very similar knapping techniques, James and Petraglia suggest that some terminal Paleolithic industries developed from Middle Paleolithic ones. We do not know who was responsible for these South Asian industries or, in particular, who produced the Middle Paleolithic blades. It could have been archaic South Asian hominids.

Then, hypothesizing that modern humans reached South Asia during the Middle Paleolithic, they suggest that the absence of a "symbolic revolution" comparable to that which occurred in Europe and Africa was due to a particular demographic situation. I am not convinced by this argument, especially with regard to the supposed link between adornment and demography. Sparse populations living under harsh conditions with meager re- 
JAmes AND petraglia Modern Human Origins | Si7

sources would not necessarily have lacked adornment. While adornment is a marker of identity, it could have served to distinguish either people of two different communities or two persons from the same community.

Why not consider an encounter between archaic hominids and modern humans from Africa with exchange and reciprocal influences? This hypothesis would have the advantage of explaining the continuity between the Middle and the Upper Paleolithic. As James and Petraglia suggest, modern humans that reached the Indian subcontinent during the Middle Paleolithic would not yet have developed symbolic thought either in Europe (for good reason, not having reached it) or in Africa, and their industry would not have been very different from that of the local populations. This would explain why the remains of the Middle Paleolithic are similar to those of the Upper Paleolithic.

The scenario of exchange and reciprocal influence between local populations and newly arrived ones is not so incongruous if one examines what apparently happened in Europe with the Châtelperronian, which may be evidence of the confrontation of Homo neanderthalensis with $H$. sapiens arriving from the Near East via Central Europe. The differences between the original industry of the Neandertals - the Mousterian-and that of modern humans-the Aurignacian-were sufficiently marked to generate a new industry-the Châtelperronian-distinct from both.

The cultural change-with the appearance of bone tools, adornment, and so on-appeared in South Asia very much later than in Europe and in Africa and more gradually and tentatively, but if the South Asians' technology was well adapted to the environmental conditions, why would they have changed it? It is not that they had not developed symbolic thought, much less that they were incapable of it. It is important not to confuse cognitive capacities with the archaeological evidence for those capacities. I am thinking in particular of what Raymond Aron called the "retrospective illusion": why would modern humans have had to develop bone tools and adornment if they did not need them? While we are inclined to think that they ought to have done so, it is because we have difficulty imagining populations of modern humans that lacked these innovations. But technical and symbolic evolution is not inevitable.

We can ask ourselves why these improvements appeared around 28,500 years ago (the date of the earliest evidence of adornment, from the ancient horizon of $\mathrm{Ba}$ tadombalena). It may be that these innovations are not necessarily the result of an encounter between populations from the west and local South Asian populations; it could be simply convergence. Just as the invention of agriculture and animal husbandry occurred in many places in the world in the course of two or three millennia, so, perhaps, could better exploitation of organic and mineral materials - with the invention of bone tools and the improvement of the lithic industry.

At present, James and Petraglia's explanation for the emergence of new technical and symbolic behaviors does not seem to me more convincing than the other envi- ronmental arguments traditionally advanced. While I agree with them about the role of population growth in cultural change, it is for different reasons. I have elsewhere developed a proposal with regard to the cognitive conditions for invention or innovation (de Beaune 2003, 2004). It is apparent that modern humans and some of their predecessors already had the cognitive equipment necessary for the production of a new idea, but it is not enough for an invention to exist for it to be adopted and spread. Many researchers have examined the conditions, both social and technical or psychological, for the adoption of an innovation or an invention. Given that the archaeological finds reflect events that were extremely discontinuous, one can admit that the wide distribution of a phenomenon-whether a technique or anything else-indicates that it has passed the test for adoption. I suggest, therefore, that population density could have favored technical and/or "symbolic" innovations in that the conditions for the emergence of new ideas were intensified by the size of the population and the increased probability of contacts between different groups rather than because of any competition for resources.

ROBIN DENNELL

Department of Archaeology, University of Sheffield, Northgate House, West Street, Sheffield SI 4ET, UK (r.dennell@sheffield.ac.uk).9 vir o5

James and Petraglia should be congratulated on incorporating South Asia into debates about the origins of modern human behaviour. Given the size and location of this region halfway across Asia, it deserves attention as a critically important area. The best part of the paper is the discussion of the Indian late Lower and Middle Palaeolithic. They correctly highlight the scarcity of reliable dates between 400,000 and 30,000 years ago. My prediction is that as the dating improves, the Indian Middle Palaeolithic will probably acquire the same geographical variation and temporal patterning as in the Levant and extend back to $>200,000$ years ago. A major omission is a table of available South Asian absolute dates $>30,000$ years ago and a discussion of their reliability, especially those >100,000 years ago obtained in the I980s, which are probably minima. Nevertheless, they argue strongly that both the Middle and Upper Palaeolithic in South Asia are local developments and not the products of immigrant African populations.

The paper is less successful in situating the South Asian evidence within a scenario whereby modern humans dispersed out of Africa. Having concluded that there is no evidence that modern humans dispersed at the beginning and end of the Middle Palaeolithic in South Asia, the authors suggest that "an early dispersal of modern humans ... is the most parsimonious explanation of the available evidence." It is unclear when this dispersal supposedly occurred. The authors appear to contradict themselves by saying "Our hypothesis is that this initial dispersal reached South Asia during the Middle Paleolithic" (and mentioning "Middle Paleolithic 
colonizers") but also "There is no clear evidence within the South Asian Middle Paleolithic for an early dispersal." Do they therefore mean that this dispersal happened earlier, in the later part of the Lower Palaeolithic? Or that evidence for it has not yet been but eventually will be found in the Middle Palaeolithic?

Three problems with suggestions that modern humans migrated out of Africa and into South Asia during the late Lower and Middle Palaeolithic are not fully addressed: (I) their own assessment that the South Asian Middle and Upper Palaeolithic were locally derived, (2) the fact that in the Levant the late Lower Palaeolithic Yabrudian, the Middle Palaeolithic Levallois-Mousterian (used by both Neanderthals and anatomically modern humans), and the earliest Upper Palaeolithic assemblages are also distinctly non-African beyond the level of the techno-complex (see, e.g., Marks I992), and (3) the absence of skeletal evidence that anatomically modern humans actually originated in Africa. Whilst we know that modern humans were in Africa ca. 200,000 years ago, we do not know if they were in Southwestern or South Asia at that time. In Southwestern Asia the only relevant Middle Pleistocene fossil hominin specimen is from Zuttiyeh Cave, Israel, which is dated to I64,000 $\pm 2 \mathrm{I}$, 000 years ago (Schwarcz, Goldberg, and Blackwell I980) but is probably twice that age (Bar-Yosef I 998b:I67). As "virtually every opinion possible" (Sohn and Wolpoff I993:335) has been expressed about its identity, it is also not particularly diagnostic. In South Asia, the only Middle Pleistocene fossil hominin specimen is from Narmada. James and Petraglia cite Rightmire (200I: I28) as attributing it to H. heidelbergensis, but they may have meant Cameron, Patnaik, and Sahni (2004). Rightmire in fact cites Kennedy et al.(I99 I) for the identification of the Narmada specimen as $H$. heidelbergensis, but, confusingly, Kennedy et al. concluded that the Narmada specimen belonged to an early ("archaic") H. sapiens. This latter identification would of course greatly strengthen the case that modernity was indigenous to South Asia. The more important point here is the gap in the South Asian fossil hominin record between Narmada and the next youngest, which are the Sri Lankan specimens of modern humans at ca. 30,000 years ago. As James and Petraglia state, we do not know which hominin(s) made the South Asian Middle Palaeolithic. Until we have hominin skeletal data for ca. I00,000-2 50,000 years ago from Southwestern and South Asia, we cannot be certain that $H$. sapiens originated in Africa, and, for all we know, Southwestern and South Asia I 50,000-200,000 years ago may have been teeming with anatomically modern humans. The crux of the issue, as James and Petraglia recognize, is that we still lack indicators of "modern" behaviour that are archaeologically visible and unique to $H$. sapiens. They are probably correct in highlighting the importance of local demographic factors in making the capacity for "modern" behaviour archaeologically explicit and common, and that suggestion offers a useful way forward. What is evident is that claims for dispersals of modern humans from Africa that are based on inferences from modern genetic studies are not confirmed by the Palaeolithic records of either Southwestern or South Asia, and we are far from being able to integrate the evidence of and claims for archaeological, anatomical, and genetic "modernity."

TOOMAS KIVISILD

Department of Evolutionary Biology, Institute of

Molecular and Cell Biology, Faculty of Biology and

Geography, University of Tartu Estonian Biocentre,

Riia Str. 23, 5 IoIo Tartu, Estonia (tkivisil@ebc.ee).8

VII 05

James and Petraglia present a summary of recent progress in archaeological research in South Asia and a synthesis of the existing genetic, climatic, anthropological, and archaeological data on the critical time frame in which Eurasia was likely settled by anatomically modern humans. The heart of the matter is an understanding and reevaluation of some of the basic concepts of South Asian archaeology in a global context, including modern human behavior, the cultural shift(s) toward it, and the geographic spread of its manifestations. According to the "classical" view, blade technology in India is classified as Upper Palaeolithic, with the implicit assumption that it is derived from the culture arising first in the Near East and expanding approximately 40,000 years ago toward Europe. James and Petraglia argue, on the basis of the wide diversity of Late Pleistocene lithic tools in South Asia, the continuity of Middle and Upper Palaeolithic sites, and their distinctiveness from the contemporary artifacts of the Near East and Europe, that the South Asian "Upper Palaeolithic" developed largely from local roots. This suggestion contests the view that the origin of modern humans and their global spread were based on a dramatic shift in human behavior toward modernity recognizable through a package involving symbolic art, long-range exchange networks, and standardized technologies. Such a package, in theory (Klein 2000), would provide a reasonable explanation for the success of modern human expansion from the northeast corner of Africa through the Near East to replace the world's preexisting hominin populations. What does not fit this model, however, is the evidence of the restricted occurrence of this cultural package. Late Pleistocene sites in Asia and Australia associated with anatomically modern humans have produced mostly Middle Palaeolithic artifacts. James and Petraglia explain the appearance and success of the Upper Palaeolithic cultural package in the Near East in terms of demographic factors. Once the behavioral implications of the package have been neutralized, however, what cultural evidence is left to support the Northeast African exit route for modern humans in Eurasia? What remains confusing about James and Petraglia's synthesis is the discussion in support of multiple dispersals, where they note that the genetic evidence is consistent with but does not directly support the idea of a southern route of dispersal into South Asia. While genetic dating has its challenges, the phylogeographic evidence from mitochondrial DNA and Y-chromosome studies provides support for a single southern 
route (Endicott et al. 2003a, Forster and Matsumura 2005, Kivisild et al. 2003, Macaulay et al. 2005, Oppenheimer 2003, Thangaraj et al. 2005). Another Late Pleistocene dispersal, likely via the Northeast African exit route, would be supported by the evidence of particular Y-chromosome lineages, but this clearly refers to a much later period (Cruciani et al. 2004, Semino et al. 2004). Thus, as far as the genetic data are concerned, there is indeed support for multiple Late Pleistocene dispersals from Africa but only a single route for the initial expansion of modern humans outside Africa.

James and Petraglia summarize the evidence for a gradual evolution of lithic technologies in South Asia from prepared-core toward the Upper Palaeolithic. Preparedcore technology has been found not only in association with modern humans but also in sites dated to more than I00,000-200,000 years ago that are associated with archaic human populations. Therefore, as they note, this technology does not allow us to distinguish between anatomically modern and nonmodern populations. Thus the discussion of the possibility that the large landmass of the Indian subcontinent may have been the reason the replacement event took longer in South Asia becomes a circular return to the model in which the Upper Palaeolithic package defines who is modern and who is not. Would it be implausible, then, given the cultural similarity of different hominin populations in the Late Pleistocene and their ordinary potential to become "modern," that the initial dispersal from Africa along the southern route carried predominantly the same prepared-core technology with some elements of the Upper Palaeolithic package that rather quickly, by cultural adaptation or drift, became dominant in the West while the South Asian populations had more time to channel their cultural richness toward one mainstream technology?

RAVI KORISETTAR

Department of History and Archaeology, Karnatak University, Dharwad, Karnataka 580003 , India

(korisettar@yahoo.com). I4 vir 05

James and Petraglia present a refreshing summary of the Middle Palaeolithic of the Indian subcontinent and focus attention on the dispersal events of modern humans into the subcontinent. While I agree with many of their propositions, I wish to draw attention to the value of the geologic and geomorphic record for understanding evolutionary processes.

I have explained the differential distribution of $\mathrm{Pa}$ laeolithic sites in terms of a "basin" model emphasizing the existence of core and peripheral areas and a network of dispersal routes (Korisettar 2004). Some of the basins present continuous cultural development while others show variations in site density and lithic assemblage character and composition over time, as indicated in James and Petraglia's summary. Does this reflect the timing of human colonization of the subcontinent and the habitability of various habitats? Though James and Petraglia have included my model in their review, their literal translation of the Purana and Gondwana Basins as "ancient basins" is a distortion. The Asian landmass, particularly outside of the Himalayan geosyncline and the Quaternary fluvial basins, is largely made up of very ancient geological formations, hence the phrase "ancient basins" for the Purana and Gondwana Basins is inappropriate. The Palaeolithic succession in these basins is continuous and the density of sites relatively greater than in others. The parameters most important for the survival of hominins in these basins are $(a)$ their geological and geotectonic framework, $(b)$ the availability of perennial fresh water and raw materials, and $(c)$ the high biomass of a variety of food resources. Regional diversity appears to reflect the adaptation of hominins to the savanna ecosystems.

The monsoon system governs the availability of fresh water across the peninsular landmass. Groundwater movement and the permeability of rocks must have facilitated higher water-table conditions during the Pleistocene, with a highly water-saturated vadose zone that was critical to the prevalence of swampy and ponded surface-water resources across the landmass. Dyke swarms were potential areas of high water table, and the consequent spring activity continued to provide fresh water during the intervening monsoon seasons. This aspect of the habitability of landscapes is of paramount importance for the reconstruction of dispersal routes and consequent colonization patterns of hominins during the Pleistocene.

The argument that prepared-core technology was part of a dispersal event of modern humans out of Africa warrants careful scrutiny. While technological changes may be related to population movements, prepared-core technology must be considered a response to environmental change. Moreover, researchers arguing for southern dispersals seem to overlook the discontinuous distribution of Acheulean and Middle Palaeolithic sites along the coasts of the Indian peninsula. Most Middle Palaeolithic sites along the Saurashtra littoral in Gujarat are associated with lowered sea level in the Late Quaternary, and much the same is the case with Acheulean sites from this region, which are located $20-30 \mathrm{~km}$ from the coast. The evidence from the Kerala coast is nondiagnostic, and along the western seaboard there is a lack of Pleistocene sites. Coastal environments are generally devoid of fresh water and associated food resources. The dearth of hard rock outcrops would also have been a deterrent. On the plains of Tamil Nadu there is evidence of the Middle Palaeolithic, but this is in the region north of the Kaveri Valley, associated with a Gondwana basin. The north-eastern regions of the subcontinent were difficult to negotiate, and the Palaeolithic is not yet documented from this region. That the transcontinental routes were apparently more convenient is indicated by the Early and Middle Palaeolithic evidence from the Central Himalayan regions of Ladakh and Nepal (Corvinus 1995, Sharma I995, Korisettar and Rajaguru I998).

I suspect that the dispersal routes of archaic and modern human populations were similar and that the Purana and Gondwana Basins were areas of interaction and com- 
petition between hominin species. Research in these basins is needed to reconstruct the processes of replacement and to explain the diversity of the Later Pleistocene lithic assemblages. The Vindhyan Basin of central India appears to hold the key. The core areas were interconnected, and that facilitated the dispersal of the smaller hominin populations in time and space. The Later Pleistocene witnessed increased monsoon precipitation across the peninsula, though in consonance with global climatic changes. The regions adjacent to the Purana and Gondwana Basins, with a variety of cryptocrystalline mineral resources suitable for blade and bladelet technologies, began to attract populations because of their swamps and shallow bodies of water. Periodic shifts in the monsoon belts during the Pleistocene would have caused changes in the savanna biomass and necessitated hominin responses. One observes a gradual evolution of the Middle Palaeolithic assemblages towards the Upper Palaeolithic in the Vindhyas and in the lower Eastern Ghats (on the southeast coast), but this is not the case in the Deccan volcanic province of western India, where the tendency towards microlithization is quite early. This article's synthesis of the material cultural evidence drawn together from a widely scattered literature is a beginning for the assessment of the Indian Later Pleistocene record and its placement in global context.

JOHN R. LUKACS

Department of Anthropology, University of Oregon, Eugene, OR 97403-I2 I8, U.S.A. (jrlukacs@darkwing. uoregon.edu). I9 VII o5

James and Petraglia cogently evaluate a poorly understood period of South Asian prehistory and offer provocative proposals regarding human dispersal and the origin of modern behavior. The problems addressed include two main issues of general interest: the origin of modern human behavior in South Asia and the nature of the evidence for an early southern dispersal from Africa through South Asia to Australia. The authors commendably adopt a comprehensive theoretical perspective that embraces molecular genetics, paleontology, and archaeology, but South Asia presents serious practical limitations to the application of holistic and integrative research strategies when complex issues such as these are considered. The near absence of a Pleistocene hominin fossil record and the paucity of high-quality, independently verified chronometric dates make it difficult to achieve a biological perspective on dispersal and to interpret variability in tool assemblages through space and time.

Themes of continuity and diversity are not uncommon in James and Petraglia's analysis, but the implications of these patterns are not always clear. For example, are the differences in the abundance of points between the northwest and north-central regions and the southeast due to adaptation, resource availability, or tradition? Regional continuities in lithic technology suggest that indigenous cultural developments are an important aspect of South Asian cultural history. The origin of "preparedcore" methods at Kaladgi from the preceding Acheulean and the absence of a sudden shift to "classic prismatic" cores of Patne with the onset of the Late Paleolithic are notable examples.

Archaeological evidence for modern human behavior in South Asia is relatively sparse and relatively late and lacks the "revolutionary" character of the Aurignacian in Europe. James and Petraglia suggest that the reason for this is that "it is not being expressed in the form that we are expecting." This is interesting proposal for which parallels exist much later in South Asian prehistory. At the third-millennium urban site of Harappa, for example, material symbols of social or economic stratification are infrequent and subtle, in dramatic contrast to the situation in the contemporaneous cultures of Egypt or Mesopotamia (Possehl 2002). The authors regard the disconnect between the appearance of human behavioral modernity in South Asia and archaeological manifestations of explicit symbolism as linked to demographic variables and resource competition, which are subject to long- and short-term fluctuations in climate and may not have crossed some unknown demographic threshold until late in prehistory.

Two biological approaches to these issues that have been underutilized are the dental anthropology and skeletal biology of post-Pleistocene populations of South Asia. Decorative modification of anterior teeth may result in distinctive tooth shapes and surface designs or provide space for the attachment of stylish dental inlays. Dental modifications may be created using fundamental technologies by filing or incising, and these modifications may serve as symbols of status or group membership (Alt and Pinchler I998, Milner and Larsen I991). The maxillary dental arcade of burial 4 from Bhimbetka II B-33 exhibits linear vertical grooves, providing a rare but instructive example of intentional modification of anterior teeth from ca. 8,000 BP (Kennedy, Misra, and Burrow I98I). Another approach involves the use of genetically influenced variations of dental morphology to assess the degree of relationship between living and prehistoric populations. The distribution and frequency of dental traits within and among populations provide valuable evidence from which population relationships and dispersal routes can be inferred. Global variation in dental morphology has been summarized (Scott and Turner I997), and special problems of human population history such as the Asian origin of native Americans (Turner I985) and the recognition that the Asian population may be subdivided into northern (Sinodont) and southeastern (Sundadont) groups with different phenotypic dental patterns represent notable achievements (Turner I990). Variation in dental morphology of living and prehistoric peoples of South Asia has been extensively documented and specific issues of biological continuity or regional variation addressed (Hawkey I998, Hemphill, Lukacs, and Kennedy I99I, Lukacs and Hemphill I99I, Lukacs, Hemphill, and Walimbe I998). Morphological variations of the dentition among living tribes and castes and among archaeologically derived prehistoric populations 
in South Asia have the potential to make significant contributions to our understanding of routes of biogeographic dispersal and modern human origins in South Asia (Lukacs 2006). A carefully designed synthetic reappraisal of post-Pleistocene human dental variation in South Asia will help to resolve these issues with human biological data.

James and Petraglia conclude by calling attention to the enormous potential of South Asia for contributing to investigations into modern human origins and the evolution of behavior. This assertion echos the sentiments of many South Asian archaeologists and anthropologists. The subcontinent also presents obstacles to research that require creative and ingenious methods and designs. Uncovering the palimpsest of South Asian population and culture history will provide rich rewards for scholars possessing ample doses of cleverness, industry, and persistence.

\section{N. MISRA \\ G-2, B Wing, Ganga Park, Mundhwa Road, Pune 4 I I \\ 036, India (misravn@vsnl.net). I3 vi 05}

I agree with James and Petraglia that there is no change in the South Asian archaeological record which can be interpreted to indicate the appearance of anatomically modern humans around the time when they are believed to have colonized South Asia. The prepared-core technique is present in its fully developed form in a number of late Acheulian industries in the Gambhiri and the Luni Valley, in the Bhimbetka rockshelters and a number of open-air sites, and in the Tirupati and Hunsgi-Baichbal Valleys. Handaxes and cleavers also persist in some Middle Palaeolithic industries. Although blades become common only in the Upper Palaeolithic and the Mesolithic, fairly good blades are present in the Late Acheulian and Middle Palaeolithic assemblages at Bhimbetka and other sites.

A number of new cultural traits appear, however, in the later part of the Upper Pleistocene and early Holocene, including developed blade technology, bone and antler tools, the bow and arrow. haematite, art, ornaments, intentional disposal of the dead, and regular use of fire. Blades are made from prismatic cores by the pressure technique. Backed blade variants characterize the Upper Palaeolithic assemblages of the Eastern Ghats in Kurnool and Chittoor Districts, and an assemblage of long plain, backed, truncated and serrated blades, scalene triangles, and trapezes is known from the Upper/EpiPalaeolithic site of Baghor I in the Son Valley.

The earliest evidence of art is dated to about 30,000 years BP at the Upper Palaeolithic site of Patne in the form of ostrich-eggshell pieces engraved with a crisscross design. Paintings from a large number of rockshelters in central India are radiocarbon-dated to the Mesolithic but, considering their geographical spread, large number, and maturity of style, surely have their beginnings in the Upper Palaeolithic. The earliest ornaments are ostrich-eggshell beads from the Upper Pa- laeolithic at Patne and Bhimbetka. Discs cut from antler for use as earrings and components of necklaces are found with human burials at the Mesolithic site of Mahadaha in the Ganga Valley. Teeth of one of the Mesolithic skeletons at Bhimbetka bear deeply incised lines.

The earliest human burials and microlithic industries in South Asia appear in southern Sri Lanka around 34,000 BP, but as humans could have reached there only from India we can assume that burials and microlithic industries of at least the same age also existed in India. The microliths of Sri Lanka are mostly made on flakes and comprise mainly unstandardized forms of scrapers, cutters, points, etc., geometric types being present only in an amorphous form. Most of the Indian microliths, in contrast, are mass-produced microblades converted into highly developed tool forms characterized by perfect symmetry of shape and fine retouch. There are many depictions in central Indian rock paintings of the use of geometric microliths as tips and barbs of arrowheads and spearheads and of the hunting of large and medium-sized animals with bow and arrow and spear.

Perforated stone discs believed to have been used as mace heads have been found at a number of Mesolithic sites and may also have been used for hunting. Shallow querns and flat upper grinding stones are also found. The use of advanced technology would have increased the availability of food and, in conjunction with the increased food resources produced by enhanced rainfall, must have contributed to the increase in population reflected in the significant increase in the number of archaeological sites. Human burials have been found at several Mesolithic sites in Gujarat, Rajasthan, Madhya Pradesh, and Uttar Pradesh. In the last-named state they occur in large cemeteries and suggest at least seasonal sedentary settlement.

The period from about 40,000 BP to I0,000 BP witnessed a number of innovations. To what extent they were introduced by newly arrived modern humans is impossible to say. According to James and Petraglia, the timing of some of these behavioural changes corresponds with the demographic expansions proposed by Kivisild et al., but the archaeological evidence from India does not show any such expansion. It is only during the Mesolithic that a remarkable expansion is evident.

The earliest stone tool industries of Australia have little in common with the contemporary Middle Palaeolithic industries of South Asia. Their typology is entirely different, and there is no evidence in them of the use of the Levallois technique. As regards the later Small Tool Tradition, the only feature it shares with the South Asian Holocene industries is microliths. However, Australian microliths are almost entirely made on flakes and lack evolved geometric forms. More important, the bow and arrow never reached Australia. Indian microlithic technology is therefore unlikely to be the source of Australian microliths. The Australian dingo, which is anatomically very close to the Indian pariah dog and to Southeast Asian dogs, is believed to have been introduced into Australia from nearby regions such as Borneo, where the domestic dog was known by about 4,500 BP. 


\section{Reply}

HANNAH V. A. JAMES AND MICHAEL D.

PETRA GLIA

Cambridge, England. I 5 VIII 05

Given the vast and currently untapped potential of the Paleolithic record of the Indian subcontinent, our aim was to introduce the biological and cultural record of South Asia into debates about the origin and development of modern humans. Our study was interdisciplinary, and therefore we are pleased to have positive responses from practitioners in archaeology, biological anthropology, and genetics. While we are well aware of the problems in dating and the nature of the archaeological and skeletal evidence pointed out by Dennell and Lukacs, we hoped to transcend some of these current limitations in order to indicate research areas that needed improvement and to address geographic bias in human evolutionary studies. As a result, we have created a working hypothesis that can be tested as more data become available.

The commentators appear to agree with us that Middle Paleolithic core technologies gradually developed from regional Acheulean technology, and in fact Misra provides additional support for this argument. No commentator disagrees with our contention that modern humans dispersed to South Asia using Middle Paleolithic technology, in significant contrast with the contention that such spreads were accompanied by an "Upper Paleolithic package." Commentators appear to be comfortable with the notion of the technological "mosaic" presented in our article, yet we note that they continue to use the term "Upper Paleolithic," which we have rejected.

De Beaune argues that the Middle Paleolithic and Late Paleolithic technologies of South Asia could be the result of "exchange and reciprocal influences" between archaic and modern hominins. While we agree that encounters between different hominin species, if they occurred, must have influenced the cultural and social practices of both populations, we suggest that such a demographic situation may have led to the eventual extinction of the endemic species and the emergence of new forms of innovations and adaptations in the competitive environment. But such a scenario is only one of many in which population demographics could have affected cultural evolution.

De Beaune rejects the idea that increasing evidence for symbolism after 28,500 years ago is a response to increasing population size and competition and instead sees it as a product of the "cognitive conditions for invention." While the ability to produce explicitly symbolic artifacts for use in marking identity may indeed be favored under a scenario in which increased population densities lead to increased competition for resources, we also accept that sparse populations do indeed use symbolic material culture. The hypothesis we present in our paper is, however, based on a much more complicated interrelationship between demographic and cultural change. We assume that symbolic artifacts and complex technology (the components of the modern human behavioral package) would be advantageous under certain conditions but argue that even if they were "adaptive" at a given point in time they may not necessarily all have spread within a given population's cultural repertoire. The evolution of the material cultural package in a given population is dependent on the relative effects of cultural drift and natural selection, as noted by Kivisild. In small populations cultural drift has more of an impact on cultural evolution than natural selection, increasing the likelihood of variation that is adaptively neutral. Indeed, in human populations this process is further complicated precisely by our use of all material culture in identity creation and manipulation. There are anthropologically noted cases of useful (i.e., adaptive) traits' being lost because, as Shennan (2000) has noted, of the reduction of the effective population size by the selective transmission of knowledge. While we agree with de Beaune that certain conditions must be present before an innovation is adopted by a group, she does not specify how the South Asian evidence can be understood relative to "social and technical or psychological" circumstances. We suggest that the mosaic-like nature of technological innovations can be seen not only in Later Pleistocene South Asia but also in the Middle and Late Stone Age of Africa. Such patterns are best explained by population-level demographic fluctuations and the way in which they affect the driving forces of cultural evolution at the population level, natural selection and cultural drift. Similar demographic processes, including population-level increases, dispersals, contractions, and isolations, provide a parsimonious explanation for the mosaic-like appearance of modern anatomical traits in African Middle and Late Pleistocene hominin populations. We suggest, therefore, that population-level microevolutionary processes constitute a useful interpretive tool for all aspects of modern human origins.

In response to Dennell's question concerning the timing of modern human dispersals out of Africa, our position is that the eastward expansion took place during the Middle Paleolithic. We remain hesitant to assign a specific date to the initial dispersal event, but we believe that the most parsimonious explanation of the biological and cultural evidence is that the spread reached the Indian subcontinent as much as 70,000 years ago. Although Dennell argues that South Asia may have been "teeming" with anatomically modern humans by $200,000-$ I 50,000 years ago, we stand by the view that Homo sapiens arose in Africa and spread toward South Asia at a later date. We are unconvinced that the Narmada hominin, which is associated with a Late Acheulean industry, will provide support for an indigenous development of modernity.

Kivisild confuses our "multiple-dispersals" reference and our statement about the lack of genetic support for a southern dispersal route. Our argument is that the paleoanthropological evidence suggests that modern hu- 
JAmes AND petraglia Modern Human Origins | S23

mans emerged out of Africa more than once. The fossil and archaeological evidence does not necessarily correspond to the genetic evidence, which is exclusively based on modern population distributions. Hence, our argument is that genetic evidence alone does not account for all population movement and spreads, especially those that may have proved unsuccessful in the long term.

While Kivisild does not dispute our argument that the Late Paleolithic evidence provides support for demographic expansions at ca. 30,000-20,000 years ago, Misra contends that there is no archaeological evidence for such an expansion. We argue that some of the "Mesolithic" sites that Misra notes to be part of a "remarkable expansion" may, in fact, represent evidence for population increase during the 30,000-20,000-year time frame. It is unfortunate that few of the many thousands of microlithic sites on the subcontinent have been dated.

Korisettar's emphasis on the importance of the natural resources associated with the Gondwana and Purana Basins is entirely appropriate, and we accept that our term "ancient basins" may not be a correct geological usage. We agree that the basins would have been attractive settings for hominins and the place where population interactions and competition would have occurred, but we would like to see supportive evidence for his conclusions. His hypothesis of transcontinental routes is of great interest, as it contrasts with the coastal dispersal routes often depicted in Out-of-Africa models. While he points to the discontinuous evidence for coastal migration, we do not think it should be rejected until systematic survey efforts have been made to determine the presence or absence of littoral sites.

Kivisild and Misra make explicit reference to the potential connections and contrasts in the prehistories of South Asia and Australia. While dispersal models often discuss movement of modern humans out of Africa via South Asia and toward Australia, the archaeological evidence for such a dispersal is rarely taken into account. Misra contends that the stone tool industries of South Asia and Australia differ substantially, implying that the archaeological record of South Asia cannot be used to support the initial colonization of Australia. While Misra's contention cannot be disproved, we might also surmise that the lack of a clear industrial signal between the two regions may relate to the variety of adaptive responses that were undertaken by modern humans as they dispersed toward Australasia.

The origin of behavioral modernity remains a controversial topic in the current paleoanthropological literature. As research intensifies in Africa and Europe, many of the initial hypotheses presented to explain the "behavioral" origins of the human species have been found to be flawed. By presenting a hypothesis created from a South Asian perspective we aimed both to raise the profile of an important but often ignored region and to suggest a way in which the various records from a number of world regions could be reconciled. We are therefore extremely grateful to our commentators for joining us in debating our ideas. How successful our hypothesis proves to be in explaining the origin of behavioral mo- dernity can be evaluated only on the basis of more field data. The research currently being undertaken by our South Asian colleagues allows us to be hopeful that such a point will be reached in the near future.

\section{References Cited}

A HMED, N. I984. The Stone Age cultures of the Upper Son Valley, Madhya Pradesh. Delhi: Agam Kala Prakashan.

A LLCHIN, B. I959. The Indian Middle Stone Age. Bulletin of the Institute of Archaeology, London 2:I-36.

- I973. "Blade and burin industries of West Pakistan and Western India," in South Asian archaeology I97I. Edited by N. Hammond, pp. 39-50. London: Duckworth.

ALLCHIN, B., A. GOUdie, AND K. HEGDE. I978. The prehistory and palaeogeography of the Great Indian Desert. London: Academic Press.

ALT, KURT W., AND SANDRA L. PICHLER. I998. "Artificial modifications of human teeth," in Dental anthropology: Fundamentals, limits, and prospects. Edited by Kurt W. Alt, Friedrich W. Rösing, and Maria Teschler-Nicola, pp. 387-4I 5. Wien: Springer. [JRL]

A M B ROSE, S. I998. Late Pleistocene human population bottlenecks, volcanic winter, and differentiation in modern humans. Lournal of Human Evolution 34:623-5 I.

AN, Z., J. E. KUTZBACH, W. L. PRELL, AND S. C. PORTER. 2OOI. Evolution of Asian monsoons and phased uplift of the Himalaya-Tibetan plateau since Late Miocene times. Nature 4I I:62-66.

ANDREWS, J., A. SINGHVI, R. KUHN, P. DENNIS, S. K. TANDON, AND R. DHIR. I998. Do stable isotope data from calcrete record Late Pleistocene monsoonal climate variation in the Thar Desert of India? Quaternary Research 50:240-5 I.

B A R-Y O S E F, O. I998a. "The chronology of the Middle Palaeolithic of the Levant," in Neanderthals and modern humans in Western Asia. Edited by T. Akasawa, K. Aoki, and O. BarYosef, pp. 39-57. New York: Plenum Press.

. I998b. "Jordan prehistory: A view from the West," in The prehistoric archaeology of Jordan. Edited by D. O. Henry, pp. I 62-78. British Archaeological Reports International Series 705. [RD]

BAR-Y OSEF, O., AND S. KUHN. I999. The big deal about blades: Laminar technologies and human evolution. American Anthropologist IOI:I-I7.

BASKARAN, M., A. R. MARATHE, S. N. RAJAGURU, AND B. L. K. SOMAYAJULU. I986. Geochronology of Palaeolithic cultures in the Hiran Valley, Saurashtra, India. Iournal of Archaeological Science I3:505-I4.

BEAUNE, S. A. DE. 2003. "Un arbre peut cacher la forêt: Proposition pour un modèle d'évolution des techniques," in Préhistoires, art et sociétés: Mélanges Jean Gaussen. Edited by J.P. Duhard, pp. I63-67. Bulletin de la Société Préhistorique Ariège-Pyrénées 58. [sB]

- 2004. The invention of technology: Prehistory and cognition. CURRENT ANTHROPOLOGY 45:139-62. [sB]

BEDNARIK, R. I990. An Acheulian haematite pebble with striations. Rock Art Research 7:75.

. 2003. The earliest evidence of palaeoart. Rock Art Research 20:89-I35.

BLUMENSCHINE, R., S. BRANDT, AND J. D. CLARK. I983. "Excavations and analysis of Middle Palaeolithic artifacts from Patpara, Madhya Pradesh," in Palaeoenvironments and prehistory in the Middle Son Valley. Edited by G. Sharma and J. D. Clark, pp. 39-I I4. Allahabad: Abinash Prakashan.

B OWLER, J. M., H. JOHNSTONE, J. OLLEY, J. PRES COTT, R. ROBERTS, W. SHAWCROSS, AND N. 
SPOONER. 2003. New ages for human occupation and climate change at Lake Mungo, Australia. Nature 42 I:837-40.

CAMERON, D., R. PATNAIK, AND A. SAHNI. 2004. The phylogenetic significance of the Middle Pleistocene Narmada cranium from Central India. International Journal of Osteoarchaeology I4: 4I9-47. [RD]

CANN, R. L. 200I. Genetic clues to dispersal in human populations: Retracing the past from the present. Science 29I: I $742-48$.

CARAMELI, D，C. LALUEZA-FOX, C. VeRnes，M. LARI, A. CASOli, F. MALlegni, B. Chiarelli, I. DUPANLOUP, J. BERTRANPETIT, G. BARBUJANI, AND G. BERTONELLE. 2003. Evidence for a genetic discontinuity between Neanderthals and 24,000-year-old anatomically modern Europeans. Proceedings of the National Academy of Sciences, U.S.A. IOO(II):6593-97.

ClARK, J. D., AND M. A. J. Williams. I990. Prehistoric ecology, resource strategies, and culture change in the Son Valley, northern Madhya Pradesh, Central India. Man and Environment I5(I): I3-24.

CORDAUX, R., AND M. St ONEKING. 2003. South Asia, the Andamanese, and the genetic evidence for an "early" human dispersal out of Africa. American Journal of Human Genetics 72:I 586-90.

CORVINUS, G. I994. Prehistoric occupation sites in the DangDeokhuri Valleys of western Nepal. Man and Environment I $9($ I -2$): 73-89$.

1919. I995. "Quaternary stratigraphy of the intermontane Dun Valleys of Dang-Deokhuri and associated prehistoric settlements in western Nepal," in Quaternary environments and geoarchaeology of India. Edited by S. Wadia, R. Korisettar, and V. S. Kale, pp. I24-49. Bangalore: Geological Society of India. . 2002. Arjun 3, a Middle Palaeolithic site in the Deokhuri Valley, Nepal. Man and Environment 27:3 I-44.

CRUCIANI, F., R. LA FRATTA, P. SANTOLAMAZZA, D SELLITTO, R. PASCONE, P. MORAL, E. WATSON, V. GUIDA, E. B. COLOMB, B. ZAHAROVA, J. LAVINHA, G. VONA, R. AMAN, F. CALI, N. AKAR, M. RICHARDS, A. TORRONI, A. NOVElletto, AND R. S COZZARI. 2004. Phylogeographic analysis of haplogroup E3b (E-M2 I 5 ) Y chromosomes reveals multiple migratory events within and out of Africa. American Journal of Human GenetiCS 74:IOI4-22. [TK]

DEACON, H. J., AND S. WURz. 200I. "Middle Pleistocene populations of Southern Africa and the emergence of modern behaviour," in Human roots: Africa and Asia in the Middle Pleistocene. Edited by L. Barham and K. Robson-Brown, pp. 55-65. Bristol: Western Academic and Specialist Press.

DENNELL, R., H. RENDELl, M. HALIM, AND E. MOTH. I992. A 45,000-year-old open-air Paleolithic site at Riwat, northern Pakistan. Journal of Field Archaeology I9:17-33.

DeOtARE, B., M. KAJALE, S. RAJAgURU, AND N. BAS A VAIA H. 2004. Late Quaternary geomorphology, palynology, and magnetic susceptibility of playas in western margin of the Indian Thar Desert. Indian Geophysical Union 8(I):I 5-25.

DERANIYA GALA, s. U. I992. The prehistory of Sri Lanka: An ecological perspective. Colombo: Department of the Archaeological Survey, Government of Sri Lanka.

D'ERRICO, F. 2003. The invisible frontier: A multiple-species model for the origin of behavioural modernity. Evolutionary Anthropology I2:188-202.

D'ERRICO, F., C. GAILlARD, AND V. N. MisRA. I989. "Collection of non-utilitarian objects by Homo erectus in India," in Hominidae: Proceedings of the and International Congress of Human Paleontology, pp. 237-39. Milan: Editorale Jaca Book.

ENDICOTT, P., V. MACAULAY, T. KIVISILD, C. STRINGER, AND A. COOPER. 2003a. Reply to Cordaux and Stoneking. American Journal of Human Genetics 72:1 590-93. [TK]

ENDICOTT, P., M. THOMAS, P. GILBERT, C. Stringer, C. LAlueZA-FOX, G. Willer Siev, A. HANSEN, AND A. COOPER. 2003 $b$. The genetic origins of the Andaman Islanders. American Journal of Human Genetics 72:178-84.

FIELD. J., AND M. M. LAHR. 2005. Assessment of the southern dispersal: GIS-based analyses of potential routes at oxygen isotopic stage 4 . MS.

Field, J., M. Petraglia, AND M. M. LAhr. 2005. The southern dispersal hypothesis and the South Asian archaeological record: Examination of dispersal routes through GIS analysis. MS.

FORSTER, P. 2004. Ice ages and the mitochondrial DNA chronology of human dispersals: A review. Philosophical Transactions of the Royal Society, London 359:255-64.

FORSTER, P., AND S. MATSUMURA. 2005. Did early humans go north or south? Science 308:965-66.

GAO, X., AND C. NORTON. 2002. A critique of the Chinese "Middle Palaeolithic." Antiauity 76:397-4I2.

G U D Z E R, S. I980. Quaternary environment and Stone Age cultures of the Konkan, coastal Maharashtra, India. Pune: Deccan College Postgraduate and Research Institute.

HAWKEY, DIANE E. I998. Out of Asia: Dental evidence for microevolution and affinities of early populations from India/ Sri Lanka. Ph.D. diss., Arizona State University, Tempe, Ariz. [JRL]

HEMPHILL, BRIAN E., JOHN R. LUKACS, AND KENNETH A. R. KENNEDY. I99I. "Biological adaptations and affinities of Bronze Age Harappans," in Harappa excavations 1986-1990: A multidisciplinary approach to third millennium urbanism. Edited by R. Meadow and M. Kenoyer, pp. I37-82. Madison: Prehistory Press. [JRL]

HENSHILWOOD, C., F. D'ERRICO, M. VANHAEREN, K. VAN NIEKERK, AND Z. JACOBS. 2004. Middle Stone Age shell beads from South Africa. Science 304:404.

HENSHILWOOD, C. S., F. D'ERRICO, R. YATES, Z. JACOBS, C. TRIBOLO, G. DULler, N. MERCIER, J. SEALY, H. VAlladas, i. WAtTS, AND A. Wintle. 2002. Emergence of modern human behavior: Middle Stone Age engravings from South Africa. Science 295:1 278-80.

HENSHILWOOD, C., AND C. MAREAN. 2003. The origin of modern human behavior: Critique of the models and their test implications. CURRENT ANTHROPOLOGY 44:627-5 I.

HODDER, I. I982. Symbols in action; Ethnoarchaeological studies of material culture. Cambridge: Cambridge University Press.

INGMAN, M., H. KAESSMANN, S. P ̈̈̈̈BO, AND D. GYLLENSTEN. 2000. Mitochondrial genome variation and the origin of modern humans. Nature 408:708-I3.

JAMES, H. V. A. 2003. Testing theories of modern human origins: The Middle Palaeolithic of South Asia. M Phil. thesis, University of Cambridge, Cambridge, England.

JA Y A SW AL, V. 1978. Palaeohistory of India: A study of the prepared core technique. Delhi: Agam Kala Prakashan.

J O S I, R. v. I978. Stone Age cultures of Central India (Report on the excavations of rock-shelters at Adamgarh, Madhya Pradesh). Poona: Deccan College Post-Graduate and Research Institute.

JOSHI, R. V., S. V. CHITALE, S. N. RAJAGURU, R. S. PAPPU, AND G. L. B ADAM. I979-80. Archaeological studies in the Manjra Valley, Central Godavari Basin. Bulletin of the Deccan College Research Institute 5(40):67-94.

KAR, A., A. SINGHVI, S. RAJAGURU, N. JUYAL, J. THOMAS, D. BANERJEE, AND R. DHIR. 20OI. Reconstruction of the late Quaternary environment of the lower Luni Plains, Thar Desert, India. Iournal of Quaternary Science I6(I):6I-68.

K ENNEDY, к. 2000. God, apes, and fossil men: Paleoanthropology in South Asia. Ann Arbor: University of Michigan Press.

KENNEDY, KENNETH A. R., VIRENDRA N. MISRA, AND CHRISTOPHER B. BURROW. I98I. Dental mutilations from prehistoric India. CURRENT ANTHROPOLOGY 22:285-86. [JRL]

KENNEDY, K. A. R., A. SONAKIA, J. CHIMENT, AND K. K. VER M A. I99I. Is the Narmada hominid an Indian Homo erectus? American Journal of Physical Anthropology 86: 475-96. [RD] 
James and petraglia Modern Human Origins | S25

KENOYER, J., J. CLARK, J. PAL, AND G. SHARMA. I983. An Upper Palaeolithic shrine in India? Antiquity 57:88-94.

KIVISILD, T ., M. BAMSHAD, K. KALDMA, M. METSPALU, E. METSPALU, M. REIDLA, S. LAOS, J. PARIK, W. WATKINS, M. DIXON, S. PAPIHA, S. MASTANA, M. MIR, V. FERAK, AND R. VILLEMS. I999a. Deep common ancestry of Indian and western-Eurasian mitochondrial DNA lineages. Current Biology 9:I33 I-34.

KIVISILD, T., K. KALDMA, M. METSPALU, J. PARIK, S PAPIHA, AND R. VILLEMS. I999 $b$. "The place of the Indian mtDNA variants in the global network of maternal lineages and the peopling of the Old World," in Genomic diversity. Edited by R. Deka and S. Papiha, pp. I35-52. New York: Plenum Publishers.

KIVISILD, T., S. PAPIHA, S. ROOTSI, J. PARIK, K . KALDMA, M. REIDLA, S. LAOS, M. METSPALU, G. PIELBERG, M. ADOJAAN, E. METSPALU, S. MASTANA, Y. WANG, M. GÖLGE, H. DEMIRTAS, E. SCHNAKENBERG, G. DE STEFANO, T. GEBERHIWOT, M. Claustres, AND R. Villems. 2000. "An Indian ancestry: A key for understanding human diversity in Europe and beyond," in Archaeogenetics: DNA and the population prehistory of Europe. Edited by C. Renfrew and K. Boyle, pp. 267-75. Cambridge: McDonald Institute for Archaeological Research.

KIVISILD, T., S. ROOTSI, M. METSPALU, S. MASTANA, K. KALDMA, J. PARIK, E. METSPALU, M. A D OJAAN, H. TOLK, V. STEPANOV, M. GÖLGI, E. USANGA, S. PAPIHA, C. CINNIOĞLU, R. KING, L. CAVALLISFORZA，P. UNDERHILL, AND R. VILLEMS. 2003. The genetic heritage of the earliest settlers persists both in Indian tribal and caste populations. American Journal of Human Genetics 72:3 I3-32.

KLEIN, R. 2000. Archeology and the evolution of human behavior. Evolutionary Anthropology 9:17-36.

K ORISETTAR, R. 2004. Geoarchaeology of the Purana and Gondwana Basins of Peninsular India: Peripheral or paramount? Presidential address, Sixty-fifth Session of the Indian History Congress, December 28-30.

KORISETTAR, R., AND S. RAJAGURU. I998. "Quaternary stratigraphy, palaeoclimate, and the Lower Palaeolithic of India," in Early human behaviour in global context: The rise and diversity of the Lower Palaeolithic record. Edited by $\mathrm{M}$. Petraglia and R. Korisettar, pp. 304-42. London: Routledge.

KORISETTAR, R., AND R. RAMESH. 2002. "The Indian monsoon: Roots, relations, and relevance," in Indian archaeology in retrospect: Archaeology and interactive disciplines. Edited by S. Settar and R. Korisettar, pp. 23-59. New Delhi: Indian Council of Historical Research and Manohar Publishers.

K U MAR, G. I996. Daraki-Chattan: A Palaeolithic cupule site in India. Rock Art Research I 3:38-46.

KUMAR, G., G. NARVARE, AND R. K. PANCHOLI. I 988. Engraved ostrich eggshell objects: New evidence of Upper Palaeolithic art in India. Rock Art Research 5:43-53.

KUMAR, G., A. SAHNI, R. K. PANCHOLI, AND G. NAVARE. I990. Archaeological discoveries and a study of Late Pleistocene ostrich egg shells and egg shell objects in India. Man and Environment I5(I):29-40.

LAHR, M. M., AND R. FOLEY. I994. Multiple dispersals and modern human origins. Evolutionary Anthropology 3:48-60. . I998. Towards a theory of modern human origins: Geography, demography, and diversity in recent human evolution. Yearbook of Physical Anthropology 4I:I 37-76.

. 200I. "Mode 3, Homo helmei, and the pattern of human evolution in the Middle Pleistocene," in Human roots: Africa and Asia in the Middle Pleistocene. Edited by L. Barham and K. Robson-Brown, pp. 23-4I. Bristol: Western Academic and Specialist Press.

L UKACS, JOHN R. 2006. "Interpreting biological diversity in South Asian prehistory: Early Holocene population affinities and subsistence adaptations," in The evolution and diversity of humans in South Asia. Edited by Michael D. Petraglia. Dordrecht: Springer/Kluwer Academic Publishers. [JRL]

LUKACS, JOHN R., AND BRIAN E. HEMPHILL. I99I.
"Dental anthropology of prehistoric Baluchistan: A morphometric approach to the peopling of South Asia," in Advances in dental anthropology. Edited by Marc A. Kelley and Clark Spencer Larsen, pp. 77-I I9. New York: Wiley-Liss. [JRL]

LUKACS, JOHN R., BRIAN E. HEMPHILL, AND SUBHASH R. WALIMBE. I998. "Are Mahars autochthones of Maharashtra? Dental morphology and population history in South Asia," in Human dental development, morphology, and pathology: A tribute to Albert A. Dahlberg. Edited by John R. Lukacs, pp. I I9-53. Eugene: University of Oregon Anthropology Papers. [JRL]

MACAULAY, V., C. HILl, A. ACHILLI, C. RENGO, D. Clarke, W. Meehan, J. blackburn, o. Semino, r. SCOZZARI, F. CRUCIANI, A. TAHA, N. KASSIM SHAARI, J. MARIPA RAJA, P. ISMAIL, Z. ZAINUD DIN, W. GOODWIN, D. BULBECK, H. BANDELT, S. OPPENHEIMER, A. TORRONI, AND M. RICHARDS. 2005. Single, rapid coastal settlement of Asia revealed by analysis of complete mitochondrial genomes. Science 308:1034-36.

MC BREARTY, S., AND A. BROOKS. 2000. The revolution that wasn't: A new interpretation of the origin of modern human behaviour. Iournal of Human Evolution 39:453-563.

MC DOUGALL, I., F. BROWN, AND J. FLEAGLE. 2005. Stratigraphic placement and age of modern humans from Kibish, Ethiopia. Nature 433:733-36.

MA JU M DER, P. 2OOI. Ethnic populations of India as seen from an evolutionary perspective. Iournal of Bioscience 26:533-45.

MA RA The, A. R. I98 I. Geoarchaeology of the Hiran Valley, Saurashtra, India. Poona: Deccan College Postgraduate and Research Institute.

MARK S, A. I992. "Upper Pleistocene archaeology and the origins of modern man: A view from the Levant and adjacent areas," in The evolution and dispersal of modern humans in Asia. Edited by T. Akazawa, K. Aoki, and T. Kimura, pp. 230-5 I. Tokyo: Hokusen-Sha. [RD]

MELLARS, P. 2002. "Archaeology and the origins of modern humans: European and African perspectives," in The speciation of modern Homo sapiens. Proceedings of the British Academy I06. Edited by T. Crow, pp. 3 I-47. Oxford: Oxford University Press.

. 2005. The impossible coincidence: A single-species model for the origins of modern human behavior in Europe. Evolutionary Anthropology I4(I): I 2-27.

METSPALU, M., T. KIVISILD, E. METSPALU, J. PARIK, G. HUDJASHOV, K. KALDMA, P. SERK, M. KARMIN, D. BEHAR, M. THOMAS, P. GILBERT, P. ENDICOTT, S. MASTANA, S. PAPIHA, K. SKORECKI, A. TORRONI, AND R. VILLEMS. 2004. Most of the extant mtDNA boundaries in South and Southwest Asia were likely shaped during the initial settlement of Eurasia by anatomically modern humans. BMC Genetics 5:26.

MILNER, G. R., AND C. S. LARSEN. I99I. "Teeth as artifacts of human behavior: Intentional mutilation and accidental modification," in Advances in dental anthropology. Edited by M. A. Kelley and C. S. Larsen, pp. 357-78. New York: WileyLiss.

Mishra, S. I995. Chronology of the Indian Stone Age: The impact of recent absolute and relative dating attempts. Man and Environment 20(2): I I-I7.

- n.d. Mehtakheri excavations I992. MS.

MISHRA, S., M. JAIN, S. K. TANDON, A. K. SINGHVI, P. P. JOGLEKAR, S. C. BHATT, A. A. KSHIRSAGAR, S. maik, and A. Deshpande-muhkerje. I999. Prehistoric cultures and Late Quaternary environments in the Luni Basin around Balotra. Man and Environment 24(I):39-49.

MISHRA, S., S. B. OTA, AND S. NAIK. 2004. "Late Pleistocene ostrich egg shell bead manufacture at Khaparkhera, District Dhar, Madhya Pradesh," in Abstracts of Academic Symposia, Rock Art Society of India, International Rock Art Congress, Agra, 28 November to 02 December 2004, p. 22. MISRA, v. D. I977. Some aspects of Indian archaeology. Allahabad: Prabhat Prakashan. 
MISRA, v. N. 1967. Pre- and proto-history of the Berach Basin, South Rajasthan. Poona: University of Poona. . I968. "Middle Stone Age in Rajasthan," in La préhistoire: Problèmes et tendances. Edited by F. Bordes and D. de Sonneville Bordes, pp. 295-305. Paris: Centre National de la Recherche Scientifique.

. I985. "The Acheulean succession at Bhimbetka, Central India," in Recent advances in Indo-Pacific prehistory. Edited by V. N. Misra and P. Bellwood, pp. 35-47. New Delhi: Oxford I-B-H.

. 1989. Stone Age India: An ecological perspective. Man and Environment I $4(\mathrm{I}): \mathrm{I} 7-64$.

. I995a. "Geoarchaeology of the Thar Desert, North West India," in Quaternary environments and geoarchaeology of India. Edited by S. Wadia, R. Korisettar, and V. S. Kale, pp. 2 IO-30. Bangalore: Geological Society of India.

. I $995 b$. "The evolution of environment and culture in the Rajasthan Desert during the Late Quaternary," in Ancient peoples and landscapes. Edited by E. Johnson, pp. 77-103. Lubbock: Museum of Texas Tech University.

. 200I. Prehistoric human colonization of India. Lournal of Bioscience 26:49I-53I.

MISRA, V. N., S. N. RAJAGURU, R. K. GANJOO, AND R. KORISETTAR. I990. Geoarchaeology of the Palaeolithic site at Samnapur in the Central Narmada Valley. Man and Environment I $5(\mathrm{I}):$ IO8 -16 .

MISRA, V. N., S. N. RAJAGURU, D. R. RAJU, H. RAGHAVAN, AND C. GAILLARD. I982. Acheulian occupation and evolving landscape around Didwana in the Thar Desert, India. Man and Environment 6:72-86.

MURTY, M. L. K. I979. Recent research on the Upper Palaeolithic phase in India. Journal of Field Archaeology 6:30I-20.

MURTY, M. L. K., AND K. T. REDDY. I975. The significance of lithic finds in the cave areas of Kurnool, India. Asian Perspectives I 8:2 I 4-26.

NEI, M., AND S. KUMAR. 2000. "Phylogenetic trees," in Molecular evolution and phylogenetics. Edited by M. Nei and S. Kumar, pp. 73-85. New York: Oxford University Press.

O'CONNELL, J. F., AND J. ALLEN. 2004. Dating the colonization of Sahul (Pleistocene Australia-New Guinea): A review of recent research. Iournal of Archaeological Science 3 3 : $835-53$.

OPPENHEIMER, S. 2003. Out of Eden: The peopling of the world. London: Constable.

OVCHINNIKOV, I., A. GOTHERSTROM, G. ROMANOVA, V. KHARITONOV, K. LIDDEN, AND W. GOODWIN. 2000. Molecular analysis of Neanderthal DNA from the northern Caucasus. Nature 404:490-93.

PAD D A Y Y A, к. I982. Acheulian culture of Hunsgi Valley. Pune: Deccan College.

- I982-83. Stone Age sites near Bhagi Mohari, Nagpur District, Maharashtra. Bulletin of the Deccan College Research Institute 43:9 I-98.

-. I 984. "India," in Neue Forschungen Zur-Altsteinzeit. Edited by O. Bar-Yosef, pp. 345-403. Munchen: Verlag C. H. Beck. PANT, P. C. 1982. Prehistoric Uttar Pradesh (A study of Old Stone Age). Delhi: Agam Kala Prakashan.

PAPPU, R. S. I995. "The contribution of the earth sciences to the development of Indian archaeology," in Quaternary environments and geoarchaeology of India. Edited by S. Wadia, R. Korisettar, and V. S. Kale, pp. 4I4-35. Bangalore: Geological Society of India.

PAPPU, R. S., AND S. G. DEO. 1994. Man-land relationships during Palaeolithic times in the Kaladgi Basin, Karnataka. Pune: Deccan College.

P A P P U, S. I999. A study of natural site formation processes in the Kortallayar Basin, Tamil Nadu, South India. Geoarchaeology I 4: I 27-5O.

. 2001 a. A re-examination of the Palaeolithic archaeological record of northern Tamil Nadu, South India. British Archaeological Reports International Series I003.

- 200I $b$. Middle Palaeolithic stone tool technology in the Kortallayar Basin, South India. Antiquity 75:107-17.
PAPPU, S., Y. GUNNELL, M. TAIEB, J. - P. BRUGAL, AND Y. TOUCHARD. 2003. Excavations at the Palaeolithic site of Attirampakkam, South India: Preliminary findings. CURRENT ANTHROPOLOGY 44:59I-98.

PETRAGLIA， M. D. I995. "Pursuing site formation research in India," in Quaternary environments and geoarchaeology of India. Edited by S. Wadia, R. Korisettar, and V. S. Kale, pp. 446-65. Bangalore: Geological Society of India.

. 200I. "The Lower Palaeolithic of India and its behavioural significance," in Human roots: Africa and Asia in the Middle Pleistocene. Edited by L. Barham and K. RobsonBrown, pp. 2I7-35. Bristol: Western Academic and Specialist Press.

Petraglia, M. D., And A. Alsharekh. 2003. The Middle Palaeolithic of Arabia: Implications for modern human origins, behaviour, and dispersals. Antiquity 77(298):67 I-84.

PETRAGLIA, M. D., J. SCHULDENREIN, AND R. KORISETTAR. 2003. Landscapes, activity, and the Acheulean to Middle Paleolithic transition in the Kaladgi Basin, India. Eurasian Prehistory I (2):3-24.

POSSEHL, GREGORY L. 2002.The Indus civilization: A contemporary perspective. Walnut Creek: AltaMira Press.

QUINTANA-MURCI, L., O. SEMINO, H. BANDELT, G. PASSARINO, K. MC ELREAVEY, AND A. SILVANA SANTACHIARA-BENERECETTI. I999. Genetic evidence of an early exit of Homo sapiens sapiens from Africa through eastern Africa. Nature Genetics 23:437-4I.

R A J , D. R. I988. Stone Age hunter-gatherers: An ethnoarchaeology of Cuddapah region, Southeast India. Pune: Ravish Publishers.

RAJU, D. R., AND P. C. Venkatasubbaiah. 2002. "The archaeology of the Upper Palaeolithic phase in India," in Indian archaeology in retrospect: Prehistory. (Archaeology of South Asia 3.) Edited by S. Settar and R. Korisettar, pp. 85-I09. New Delhi: Indian Council of Historical Research, Manohar.

RATH, A., K. THIMMA REDDY, AND P. VIJAYA PRAKA S H. I997. Middle Palaeolithic assemblage from Ramayogi Agraharam in the red sediments in the Visakhapatnam coast. Man and Environment 22(I):3 I-38.

REDD, A., J. ROBERTS-THOMSEN, T. KARAFET, M. BAMSHAD, L. JORDE, J. NAIDU, B. WALSH, AND M. H A M MER. 2002. Gene flow from the Indian subcontinent to Australia: Evidence from the Y chromosome. Current Biology I 2:673-77.

REDD, A. J., AND M. S TONEKING. I999. Peopling of Sahul: MtDNA variation in Aboriginal Australian and Papua New Guinean populations. American Journal of Human Genetics $65: 808-28$.

RET T A LACK， G. J. I995. "Palaeosols of the Siwalik Group as a I 5 myr record of South Asia palaeoclimate," in Quaternary environments and geoarchaeology of India. Edited by S. Wadia, R. Korisettar, and V. S. Kale, pp. I23-35. Bangalore: Geological Society of India.

RiChARDS, M., C. Rengo, F. CRUCIANi, F. GRATix, J. WILSON, R. SCOZZARI, V. MACAULAY, AND A. TORRONI. 2003. Extensive female-mediated gene flow from subSaharan Africa into near eastern Arab populations. American Journal of Human Genetics 72:1058-64.

RI GHTMIRE, G. P. 200I. "Comparison of Middle Pleistocene hominids from Africa and Asia," in Human roots: Africa and Asia in the Middle Pleistocene. Edited by L. Barham and K. Robson-Brown, pp. I23-35. Bristol: Western Academic and Specialist Press.

R О в I N S O N, F. I989. The Cambridge encyclopedia of India, Pakistan, Bangladesh, Sri Lanka, Nepal, Bhutan, and the Maldives. Cambridge: Cambridge University Press.

ROYCHOUDHURY, S., S. ROY, A. BASU, R. BANERJEE, H. VISHWANATHAN, M. V. USHA RANI, S. K. SIL, M. MITRA, AND P. P. MAJUMDER. 200I. Genomic structures and population histories of linguistically distinct tribal groups of India. Human Genetics I09:339-50.

ROYCHOUDHURY, S., S. ROY, B. DEY, M. CHAKRABORTY, M. ROY, A. RAMESH, N. PRABHAKARAN, M. 
JAMES AND PETRAglia Modern Human Origins | S27

USHA RANI, H. VISHWANATHAN, M. MITRA, S. SIL, AND P. MAJUMDER. 2000. Fundamental genomic unity of ethnic India is revealed by analysis of mitochondrial DNA. Current Science 79: I 82-92.

SALI, s. A. I989. The Upper Palaeolithic and Mesolithic cultures of Maharashtra. Pune: Deccan College Post-Graduate and Research Institute.

S A N K A L I A, H. D. I964a. Middle Stone Age cultures of India and Pakistan. Science I 46:365-76.

. I964b. Stone Age tools: Their techniques and probable functions. Pune: Deccan College Post-Graduate and Research Institute.

S A N K A L IA, H. D. I974. Prehistory and protohistory of India and Pakistan. Poona: Deccan College.

SCHWARCZ, H. P., P. D. GOLDBERG, AND B. BLACK WELL. I980. Uranium series of dating of archeological sites in Israel. Israel Journal of Earth Sciences 29:I 57-65. [RD]

SCOTT, G. RICHARD, AND CHRISTY G. TURNER, II. I997. The anthropology of modern human teeth: Dental morphology and its variation in recent human populations. Cambridge: Cambridge University Press. [JRL]

SEMINO, O., C. MAGRI, G. BENUZZI, A.A. LIN, N. AL-ZAHERY, V. BATTAGLIA, L. MACCIONI, C. TRIANTAPHYLLIDIS, P. SHEN, P. J. OEFNER, L. A. ZHIVOTOVSKY, R. KING, A. TORRONI, L. L. CAVALLI-SFORZA, P. A. UNDERHILL, AND A. S. SANTA C H I A RA - B E N E RE C E T T I. 2004. Origin, diffusion, and differentiation of Y-chromosome haplogroups E and J: Inferences on the Neolithization of Europe and later migratory events in the Mediterranean area. American Journal of Human Genetics 74: IO23-34. [TK]

SHARMA, G. R., AND J. D. CLARK. I983. Palaeoenvironments and prehistory in the Middle Son Valley. Allahabad: Abinash Prakashan.

SHARMA， K. K. I995. "Quaternary stratigraphy of the intermontane dun valleys of Dang-Deokhuri and associated prehistoric settlements in western Nepal," in Quaternary environments and geoarchaeology of India. Edited by S. Wadia, R. Korisettar, and V. S. Kale, pp. I24-49. Bangalore: Geological Society of India. [RK]

SHEN NAN, S. 2000. Population, culture history, and change. CURRENT ANTHROPOLOGY 4:8 I I-35.

. 200r. Demography and cultural innovation: A model and its implications for the emergence of modern human cultures. Cambridge Archaeological Journal i I (1):5-16.

sOHN, S., AND M. H. WOLPOFF. I993. Zuttiyeh face: A view from the East. American Journal of Physical Anthropology 9I:325-47. [RD]

SONAWANE, V. H. I984. Prehistoric cultures of the Panchmahals, Gujarat. Man and Environment 8:20-30.

SRIVASTAVA, P., I. B. SINGH, M. SHARMA, AND A. K.
S IN G H V I . 2003. Luminescence chronometry and late Quaternary geomorphic history of the Ganga Plain, India. Palaeogeography, Palaeoclimatology, Palaeoecology I97(I-2): I 5-4I.

S T R I N GER, C. 2000. Coasting out of Africa. Nature 405:24-27. . 200I. "The morphological and behavioural origins of

modern humans," in The speciation of modern Homo sapiens. Proceedings of the British Academy ro6. Edited by T. Crow, pp. 23-30. Oxford: Oxford University Press.

THANGARA , K., G. CHAUBEY, T. K IVISILD, A. G. REDDY, V. KUMAR SINGH, A. A. RASALKAR, AND L. S INGH. 2005. Reconstructing the origin of Andaman Islanders. Science 308:996.

TH I M A REDDY, K. I977. Billasurgam: An Upper Palaeolithic cave site in South India. Asian Perspectives 20:206-27.

TURNER, CHRISTY G., II. I985. "The dental search for Native American origins," in Out of Asia: The peopling of the Americas and the Pacific. Edited by R. Kirk and E. Szathmary, pp. 3I-78. Canberra: Journal of Pacific History. [JRL]

. I990. The major features of Sundadonty and Sinodonty, including suggestions about East Asian microevolution, population history, and late Pleistocene relationships with Australian Aboriginals. American Journal of Physical Anthropology 82:295-3I7. [JRL]

VIJAYA PRAKASH, P., A. RATH, AND S. KRISHNA RAO I 995. Prehistoric cultural evidence from Borra Limestone Caves, Eastern Ghats. Man in India 75(2):163-73.

WALTER, R. C., R. T . BUFFLER, J. HENRICH BRUGGEMANN, M. GUILLAUME, S. BERHE, B. NEGASSI, Y. LIBSEKAL，H. CHENG，R. LAWRENCE EDWARDS，R. VON COSEL, D. NERAUDEAU, AND M. GAGNON. 2000. Early human occupation of the Red Sea coast of Eritrea during the last interglacial. Nature 405:65-69.

WESTGATE, J., R. SHANE, N. PEARCE, W. PERKINS, R. KORISETTAR, C. CHESNER, M. WILLIAMS, AND S. A CHA RYYA. I998. All Toba tephra occurrences across peninsular India belong to the 75,000 yr BP eruption. Quaternary Research 50:107-I2.

WHITE, M., AND N. ASHTON. 2003. Lower Palaeolithic core technology and the origins of the Levallois method in northwestern Europe. CURRENT ANTHROPOLOGY 44:598-609.

White, T., B. ASFAW, D. DE GUStA, H. Gilbert, G. RICHARDS, G. SUWA, AND F. CLARK HOWELL. 2003. Pleistocene Homo sapiens from Middle Awash, Ethiopia. Nature 423:742-47.

WILLIAMS, M. A. J., AND M. F. CLARKE. I995. "Quaternary geology and prehistoric environments in the Son and Belan Valleys, North Central India," in Quaternary environments and geoarchaeology of India. Edited by S. Wadia, R. Korisettar, and V. S. Kale, pp. 282-309. Bangalore: Geological Society of India. 